\title{
Biosensing and Delivery of Nucleic Acids Involving Selected Well-Known and Rising Star Functional Nanomaterials
}

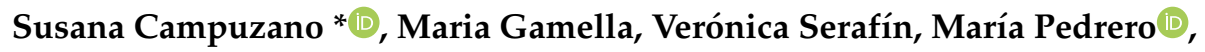 \\ Paloma Yáñez-Sedeño * and José Manuel Pingarrón * $\mathbb{C}$ \\ Departamento de Química Analítica, Facultad de CC. Químicas, Universidad Complutense de Madrid, \\ E-28040 Madrid, Spain; mariagam@quim.ucm.es (M.G.); veronicaserafin@ucm.es (V.S.); \\ mpedrero@quim.ucm.es (M.P.) \\ * Correspondence: susanacr@quim.ucm.es (S.C.); yseo@quim.ucm.es (P.Y.-S.); pingarro@quim.ucm.es (J.M.P.); \\ Tel.: +34-3944219 (S.C.); +34-3944317 (P.Y.-S.); +34-3944315 (J.M.P.)
}

Received: 24 October 2019; Accepted: 12 November 2019; Published: 14 November 2019

check for updates

\begin{abstract}
In the last fifteen years, the nucleic acid biosensors and delivery area has seen a breakthrough due to the interrelation between the recognition of nucleic acid's high specificity, the great sensitivity of electrochemical and optical transduction and the unprecedented opportunities imparted by nanotechnology. Advances in this area have demonstrated that the assembly of nanoscaled materials allows the performance enhancement, particularly in terms of sensitivity and response time, of functional nucleic acids' biosensing and delivery to a level suitable for the construction of point-of-care diagnostic tools. Consequently, this has propelled detection methods using nanomaterials to the vanguard of the biosensing and delivery research fields. This review overviews the striking advancement in functional nanomaterials' assisted biosensing and delivery of nucleic acids. We highlight the advantages demonstrated by selected well-known and rising star functional nanomaterials (metallic, magnetic and Janus nanomaterials) focusing on the literature produced in the past five years.
\end{abstract}

Keywords: functional nanomaterials; AuNPs; magnetic nanoparticles; janus nanoparticles; AuNWs; nucleic acids; biosensing; delivery

\section{Introduction}

Today, there is an increasing demand for the simple, sensitive, rapid and accurate determination of nucleic acids in fields such as clinical diagnostics, environmental monitoring and food quality control, as well as for the delivery of functional nucleic acids for therapeutic purposes.

Although some of the available conventional methodologies for the determination of nucleic acids provide high sensitivity and sampling frequency, they involve multistep, complex and time-demanding protocols. Within this context, electrochemical and optical nucleic acid biosensing in connection with a wide variety of functional nanomaterials are interesting alternatives for the simple and rapid determination of target nucleic acids meeting the required sensitivity and selectivity in actionable time frames for real-world applications [1,2].

It is important to point out that due to its great clinical relevance, the intracellular biosensing of certain nucleic acids, such as miRNAs or mRNA transcripts, is also of particular interest [3]. The currently available intracellular detection methods require long incubation times $(\sim 14 \mathrm{~h})$ and a high cell density suspension, which means that thousands of cells are profiled simultaneously, losing important information, including cell identity, and suffering from heterogeneity across cell 
populations. Accordingly, methods able to perform nucleic acids biosensing at single-cell resolution are urgently needed.

On the other hand, the intracellular delivery of functional nucleic acids, such as RNA transfection agents, able to perform efficient therapeutic actions still needs to overcome important challenges, including the lack of targeting modalities, limited loading efficiency, internalization barriers, and biocompatibility issues [3,4]. In this context, the ultrasound-assisted efficient internalization and intracellular mobility demonstrated by cell viability compatible gold nanowires (AuNWs) proves to be very promising to address such challenges.

This review critically discusses the capabilities provided by selected well-known and rising star functional nanomaterials for the biosensing and delivery of nucleic acids through a discussion of cutting-edge applications reported mostly in the last 5 years and itemized by the nanoscale material and the type of transduction (optical or electrochemical). This review focuses on these nanomaterials due to the excellent capabilities that gold nanomaterials (nanoparticles, AuNPs, and nanowires, AuNWs) and Janus and/or magnetic type nanodevices exhibit to improve the efficiency and reduce the time of nucleic acid biosensing and delivery through pre-concentration, guided at will, self-propulsion, or cellular internalization, without compromising viability and single-cell resolution.

\section{AuNPs, AuNWs, Janus and Magnetic Nanoparticles: Synthesis and Functionalization}

AuNPs, AuNWs, Janus and magnetic nanoparticles are functional nanomaterials with very interesting properties to be used in the development of efficient strategies for biosensing and the controlled release of nucleic acids. The main characteristics, opportunities and versatility provided by these four types of nanomaterials in such fields are briefly discussed in the next subsections.

\subsection{AuNPs}

AuNPs, which exhibit outstanding conductivity, chemical inertness and biocompatibility, have been largely studied as electrode materials, catalytic labels, carriers of signal elements and electron transfer regulators to enhance the performance of nucleic acid biosensing [2]. Due to the high applicability of AuNPs, a wide array of solution-based approaches have been developed in the past few decades to control their size, monodispersing, morphology and surface chemistry [5]. However, the protocol most widely employed to prepare dilute solutions of moderately stable spherical AuNPs with diameters between 10 and $20 \mathrm{~nm}$ involves treating hydrogen tetrachloroaurate $\left(\mathrm{HAuCl}_{4}\right)$ with citric acid in boiling water, where the citrate acts as both a reducing and stabilizing agent [6].

Considering the large number of reported applications for nucleic acid biosensing using AuNPs and the valuable recent reviews of this topic [2,7], only the most relevant characteristics of AuNPs and a few of the applications considered representative examples of their different uses are discussed in this article.

The use of AuNPs as electrode modifiers provides huge active surface area and facilitates the electron transfer processes at the sensing interface, thereby granting a high sensitivity to biosensors. In addition to the improved conductivity and the catalytic activity of AuNPs, nanostructured surfaces with these nanoparticles greatly enhance the amount of immobilized thiolated probes and allow their favorable orientation and spacing, thus ensuring the target accessibility and improving the hybridization efficiency [2,8-11]. The great biocompatibility of AuNPs is essential to keep the biological activity of the biomolecules attached to their surface, which produces the attractive storage stability of the prepared bioplatforms $[10,11]$.

AuNPs have also been used as catalytic artificial labels instead of enzymes in nucleic acid biosensing, thus filling critical gaps related to the low thermal and environmental stability of enzymes. Furthermore, unlike the little number of active sites present in enzymes (often just one), AuNPs hold abundant active locus, allowing the production of electrocatalytic signals higher than those obtained with enzymes and therefore, resulting in a higher sensitivity [2,12]. Furthermore, due to AuNPs' wide specific surface area, they can be filled with a high number of labels and used for amplified detection 
of nucleic acids. Indeed, AuNPs have been functionalized with unlabeled [13] or redox-labeled [14] nucleic acid probes, redox molecules [15,16], and enzymes or DNAzymes.

The outstanding conductivity of AuNPs has also been used in the development of biosensing methodologies in which the target binding is detected through AuNPs-mediated or inhibited electron transfer [17].

\subsection{Magnetic Nanomaterials}

Both the optical and electrochemical biosensing of nucleic acids in complex matrices require a previous separation of the target nucleotides from their native environment in order to concentrate them and avoid fouling of the transducer surface. The use of magnetic nanomaterials is one of the easiest and most efficient methodologies to perform this step. The magnetic pre-concentration step is also advantageous for eliminating interfering compounds, shortening the analysis time and decreasing stress-induced damages to biomolecules [18].

Among the magnetic nanomaterials, superparamagnetic iron oxide nanoparticles (MNPs), with diameters usually ranging between units and various tens of nanometers, have significantly impacted the biosensing of nucleic acids due to the great advantages they provide: large area, easy functionalization and communication with similarly sized biomacromolecules, peroxidase-like activity, rapid assay kinetics, improved sensitivity, matrix effect minimization and easy and effective control of their mobility by an external magnetic field [2,19-25]. In these biosensing approaches, MNPs can be used as transducer modifiers, as solid nanosupports to perform the affinity assay, which avoids complex and laborious protocols for modifying transducer surfaces [18,26-30], and as labels or nanocarriers of signaling molecules for signal amplification $[31,32]$.

Magnetite $\left(\mathrm{Fe}_{3} \mathrm{O}_{4}\right)$ and maghemite $\left(\gamma-\mathrm{Fe}_{2} \mathrm{O}_{3}\right)$ are the most common MNPs used for biosensing applications [33] due to their biodegradability and high biocompatibility. Diverse physical, chemical, and microbial methods have been proposed for the synthesis of MNPs [34]. Currently, a wide variety of uncoated MNPs or MNPs coated with different functional groups (amine, carboxylic acid, aldehyde, thiol, epoxy, hydroxyl, streptavidin, proteins A and G, albumin, biotin, tosyl) are commercially available. Such coatings minimize agglomeration, confer proper biocompatibility and allow MNPs' modification with biological molecules such as antibodies, DNA, RNA, and aptamers, which have fueled the development of many biosensing strategies. Regarding core-shell MNPs, $\mathrm{Fe}_{3} \mathrm{O}_{4} @ \mathrm{Au}[18,26-28,32]$ and $\mathrm{Fe}_{3} \mathrm{O}_{4} @ \mathrm{SiO}_{2}$ are the most commonly employed. While the presence of $\mathrm{Au}$ assures the excellent conductivity and adsorption ability of the nanomaterial and facilitates the functionalization with thiolated molecules through self-assembly $[29,35,36]$, the $\mathrm{SiO}_{2}$ surface enhances the stability of nanoparticles and provides a good surface for the binding of bioreagents [37,38]. $\mathrm{TiO}_{2}$ and metal-doped iron oxides ( $\mathrm{MFe}_{2} \mathrm{O}_{4}$, with $\mathrm{M}=\mathrm{Co}$ or $\mathrm{Mn}$, among others) have also been explored for biosensing purposes [19,37]. Moreover, coatings of MNPs with polymers such as polyaniline [31] and chitosan [39] allow the increase of the biomolecules' immobilization capacity. In addition, the combination of MNPs with carbon nanomaterials such as carbon nanotubes or graphene [36] allows the synergetic properties of the resulting nanocomposites to be used profitably.

\subsection{Janus Nanoparticles}

Unlike conventional nanoparticles, two-faced Janus nanodevices, which can be prepared with different morphologies and shapes (Figure 1a) [40], provide anisotropy in structure, constitution, and surface chemistry. These characteristics allow their use to perform complementary functions, achieving outcomes not feasible in the biosensing and cargo delivery areas using conventional nanoparticles [40-44]. Furthermore, analytical functions such as targeting or sensing are spatially decoupled by the surface anisotropy of Janus particles; this allows selective bioconjugation in the spatial environment and provides improved functions and properties such as dual targeting and biosensing [45], not achievable when other single structured or heterogeneous non-Janus nanoparticles are used. This particular performance opens exciting opportunities for the construction of truly 
multifunctional entities [40,46]. Moreover, the Janus balance, i.e., the surface area ratio derived from the different types of surface compositions in both faces of the nanoparticle, can be modified at will, making these particles a unique category of tailored nanomaterials in contrast to other NPs. There is a wide variety of synthetic strategies available which have evolved rapidly to adapt Janus nanoparticles to different applications. These synthetic methods can be classified as (a) masking or template, (b) direct deposition, (c) phase separation, and (d) self-assembly. Moreover, Janus nanoparticles may incorporate a magnetic material to allow magnetic driving [43,44]. Regarding biosensing, these unique nanoparticles have been exploited as transducer modifiers $[47,48]$ and advanced nanocarriers of signaling molecules for signal amplification [49,50].

One particular type of Janus nanoparticles is Au-Pt catalytic nanowires, prepared by sequential electrodeposition in the membrane templates [51]. These nanowires can self-propel at a speed of around $10 \mu \mathrm{m} \mathrm{s}^{-1}$ in a $5-10 \% \mathrm{H}_{2} \mathrm{O}_{2}$ solution. The production of protons and electrons at the extreme of the nanowire due to platinum catalyzed oxidation is responsible for the autonomous nanomotor advancement in the platinum end pointed direction (Figure 1b). It has been shown that the presence of silver ions in the $0.5-100 \mu \mathrm{M}$ concentration range) provokes a significant speed-up of the nanowires' movement, this being ascribed to an improvement in the platinum catalytic activity after underpotential silver deposition [52]. Moreover, these nanowires can be made magnetic by incorporating a ferromagnetic nickel segment into the wire (magnetic Janus $\mathrm{Au}-\mathrm{Ni}-\mathrm{Pt}$ nanowires), which makes them easy to guide at will with a simple magnet [53].

a)

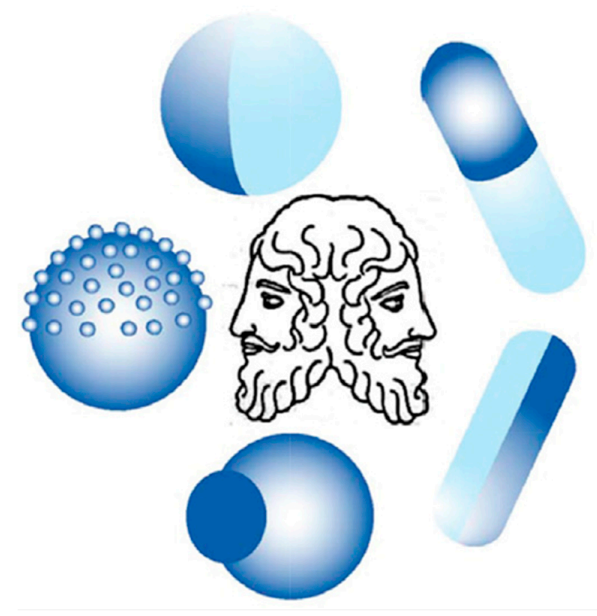

b)

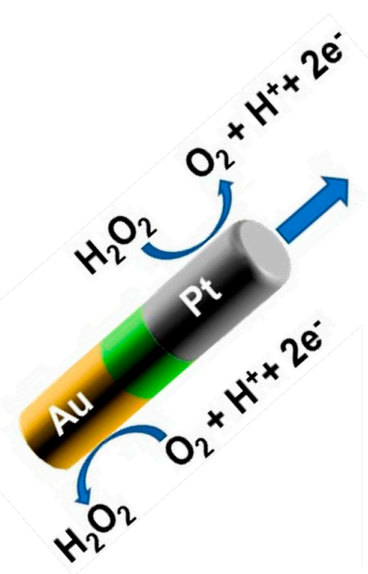

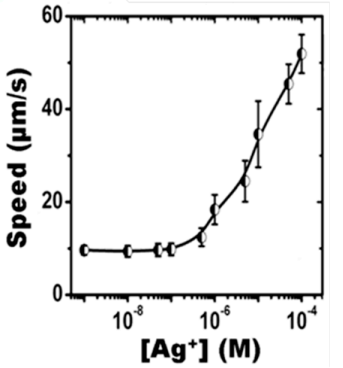

Figure 1. Schematic diagrams illustrating the different morphologies and shapes described for Janus particles (a). Au-Pt catalytic nanowires propelled in $5-10 \% \mathrm{H}_{2} \mathrm{O}_{2}$ solutions due to a self-electrophoretic mechanism and the dependence of the Au-PtNWs' speed in $5 \% \mathrm{H}_{2} \mathrm{O}_{2}$ solutions containing different concentrations (0.5-100 $\mu \mathrm{M})$ of $\mathrm{AgNO}_{3}$ (b). Reprinted and adapted from [40] (a) and [52,54] (b), with permission. Copyright RSC, 2016 (a), ACS, 2009 and MDPI, 2018 (b).

\section{4. $A u N W s$}

AuNWs prepared by a template-directed electrodeposition protocol have demonstrated ultrasound propulsion, rapid penetration through cellular membranes and remain acoustically active in the intracellular space $[3,4,55]$. The fast cell internalization and rapid intracellular movement under the acoustic field have shown the great potential of AuNWs to perform efficient and accelerated biosensing or delivery tasks inside cells without compromising their viability, even when using a high AuNWs concentration. AuNWs can be employed alone [4] or in combination with other nanomaterials such as graphene oxide [3], and conveniently modified with nucleic acids using thiol chemistry. 


\section{Biosensing and Delivery of Nucleic Acids: Roles, Opportunities and Cutting-Edge Applications of AuNPs, Magnetic Nanomaterials, Janus Nanoparticles and AuNWs}

The unthinkable possibilities offered by the functional nanomaterials commented on in the previous sections have added new dimensions to the efficient biosensing and delivery of functional nucleic acids with cutting-edge applications in connection with optical and electrochemical transduction. As presented in the following subsections, these applications exploit the multiple uses of AuNPs (as transducer modifiers, catalytic labels, nanocarriers and electron transfer regulators), the pre-concentration and on-demand guidance capabilities of magnetic nanomaterials, the dual functionalities of Janus-type nanomaterials and the self-propulsion, internalization and single-cell resolution of AuNWs.

Tables 1 and 2 summarize the relevant analytical characteristics of representative cutting-edge applications reported in the last five years for the biosensing and delivery of nucleic acids, exploiting the advantages of functional nanomaterials and using optical and electrochemical detection. The rationale and main features of these applications are critically discussed in the following sections which are classified according to the detection technique and the type/use of the functional nanomaterial.

\subsection{Optical Biosensing or Delivery of Nucleic Acids Using Functional Nanomaterials}

Wang's group (University of California San Diego) was a pioneer in the use of magnetic catalytic Janus $\mathrm{Au}-\mathrm{Ni}-\mathrm{Pt}$ nanowires for the optical biosensing of nucleic acids, profiting from the specific speeding up of these Janus magnetic nanowires when working with $\mathrm{Ag}^{+}$[52]. For the first time, the distance they travelled was used as an analytical signal [56]. The biosensing approach was implemented for the determination of a 30 mer synthetic target DNA or Escherichia coli (E. coli) $16 \mathrm{~S}$ mRNA. A sandwich hybridization format was employed on a gold electrode fabricated by photolithography and modified with a ternary monolayer comprising a thiolated specific DNA capture probe, dithiotreitol (DTT) and mercaptohexanol (MCH), and a detector DNA probe modified with Ag nanoparticles (AgNPs). Once the sandwich hybridization assay was completed, a drop of $\mathrm{H}_{2} \mathrm{O}_{2}$ solution was cast on the electrode surface and the AgNPs were rapidly dissolved. The resulting $\mathrm{Ag}^{+}$enriched $\mathrm{H}_{2} \mathrm{O}_{2}$ solution was mixed with an $\mathrm{Au}-\mathrm{Ni}-\mathrm{Pt}$ nanowires suspension and their speed (or the distance travelled) increased with the target nucleic acid concentration and was measured at a defined time (Figure 2). The detection of 40 amol synthetic DNA and 2000 colony forming units (cfu) $\mathrm{mL}^{-1}$ of E. coli was accomplished directly in raw bacterial lysates, multiple readings being possible in each test, thus reducing the false positives or negatives probability. However, catalytic nanowires' locomotion is limited to low ionic strength environments, which decreases their utility for biosensing in real media [51,57]. In comparison, acoustically propelled AuNWs, which are cytocompatible, are able to internalize and effectively set in motion in high ionic concentration media and complex biological fluids, providing higher advantages for nucleic acid biosensing [3,58]. 


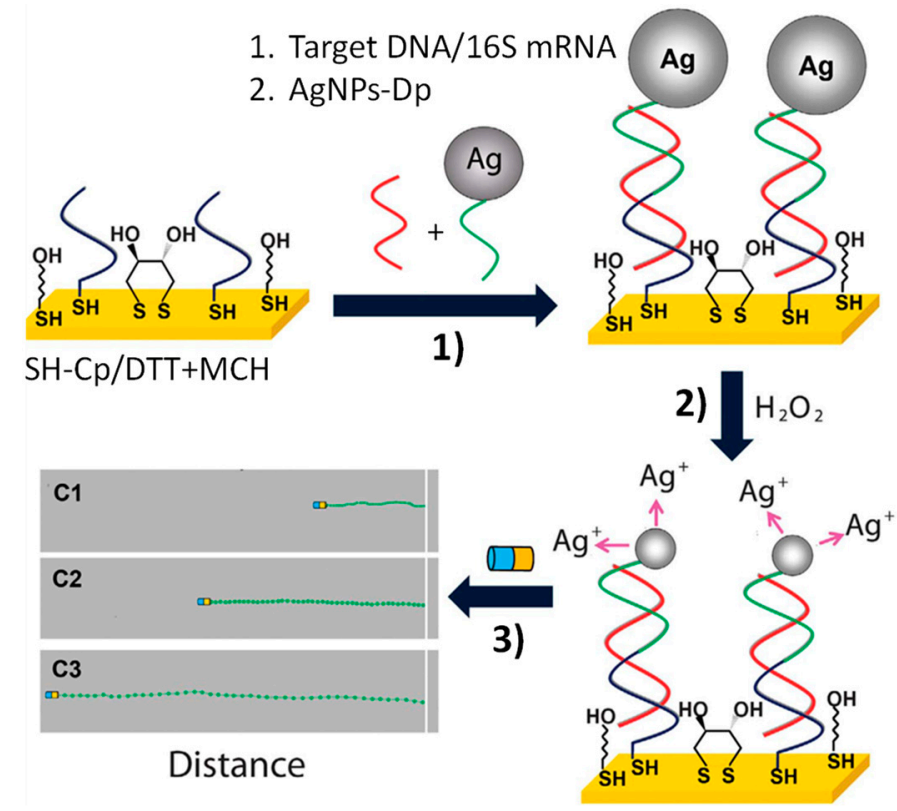

Figure 2. Optical biosensing of nucleic acids using magnetic Janus $\mathrm{Au}-\mathrm{Ni}-\mathrm{Pt}$ nanowires. Sandwich hybridization performed at a $16 \times \mathrm{AuEs}$ array modified with a ternary self-assembled monolayer (SAM) composed of a thiolated capture probe, dithiothreitol and mercaptohexanol (SH-CP/DTT $+\mathrm{MCH})$ and using a AgNPs-Dp (1). Dissolution of AgNPs tags in the presence of $\mathrm{H}_{2} \mathrm{O}_{2}$, leading to $\mathrm{Ag}^{+}$-enriched solution (2). Visual detection of the magnetic Janus Au-Ni-Pt nanowires' motion in the $\mathrm{Ag}^{+}$-enriched solution, resulting after increasing the target nucleic acid concentration (3). Reprinted and adapted from [56] with permission. Copyright Springer Nature, 2010.

The pioneering work of Wang's group demonstrated the excellent features offered by acoustic propelled AuNWs for single-step biosensing and the delivery of nucleic acids of different natures: microRNAs (miRNAs), messenger RNA (mRNA), silencing RNA (siRNA), and single-guide RNA (sgRNA) at single-cell resolution.

Regarding intracellular miRNA biosensing, graphene oxide (GO)-coated AuNWs (GO-AuNWs), were prepared by covalent immobilization of GO using 1-ethyl-3-(3-dimethylaminopropyl) carbodiimide/N-hydroxysuccinimide (EDC-NHS) chemistry on cysteamine SAM-modified AuNWs. Thereafter, GO-AuNWs were functionalized with a fluorescent dye (fluorescein amidine, 6-FAM)-labeled single-stranded DNA (ssDNA) complementary to the target miRNA (ssDNA@GO-AuNWs) (Figure 3a) [3]. The fluorescence, quenched by $\pi-\pi$ interaction between GO and the dye-labeled ssDNA, was recovered upon displacement of the dye-ssDNA probe from the GO-quenching motor surface after cell internalization in the presence of the target miRNA, thus leading to intracellular "OFF-ON" fluorescence switching (see Figure $3 \mathrm{~b}$ ). In a few minutes, the ssDNA@GO-AuNWs discriminated the different expression levels of target miRNA-21 in two types of intact cancer cells (MCF-7 and HeLa). The efficient intracellular propulsion of these functional nanowires accelerated the intracellular hybridization toward rapid "on the move" miRNAs detection with single-cell resolution. Indeed, while $\sim 60 \%$ recovery of the fluorescence intensity was observed within $5 \mathrm{~min}$ under dynamic conditions, $30 \mathrm{~min}$ were required to recover half of the fluorescence under static conditions. The same group recently reported a similar strategy for the detection of human papillomavirus (HPV)-associated oropharyngeal cancer (OPC) by targeting HPV16 E6 mRNA transcripts [58]. The method allowed the determination of HPV16 E6 mRNA transcripts both extracellularly (in the total RNA extracted from HPV-positive OPC cells) and within intact OPC cells, with a 2.3 times higher sensitivity working under dynamic conditions compared to static conditions. 
a)

1) Cys-AuNWs

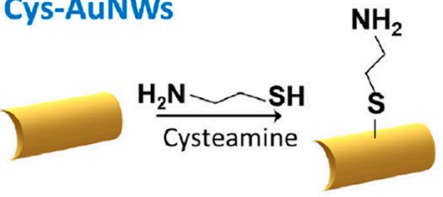

2) Activated GO

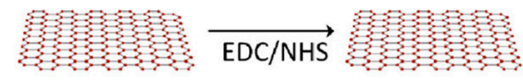

4) Quenched probe

3) GO AuNWs
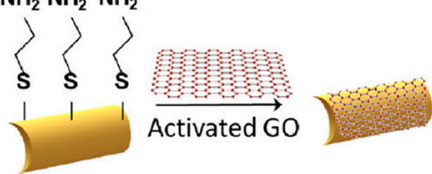

)

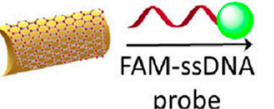

s

probe

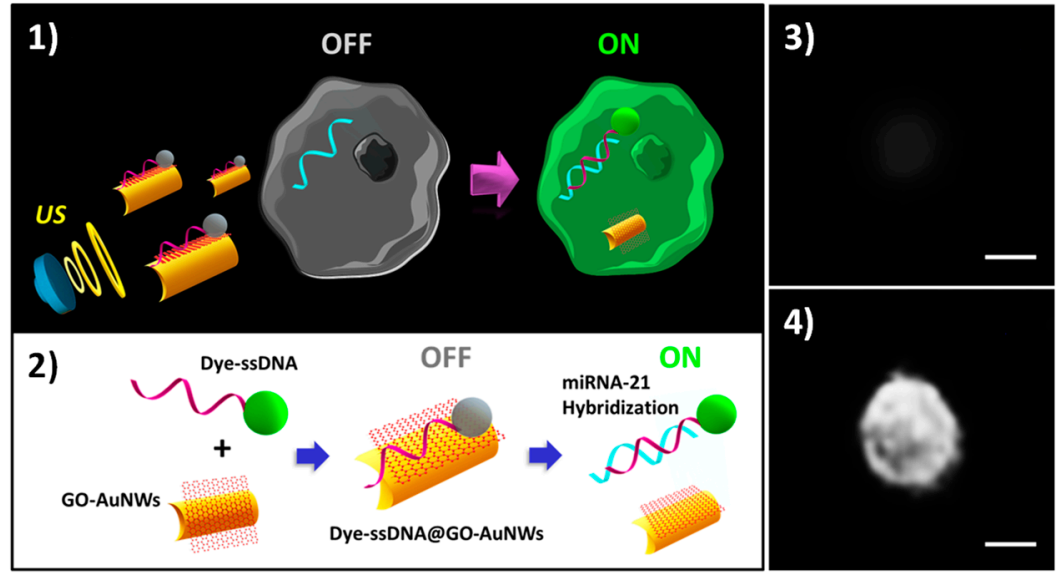

Figure 3. Intracellular biosensing of target miRNA-21 using ultrasound (US)-propelled ssDNA@GO-AuNWs. Schematic illustrations of the steps involved in the ssDNA@GO-AuNWs preparation (a) and the "OFF-ON" fluorescent switching system (b) for the specific detection of miRNA-21 in intact cancer cells (1); steps involved: immobilization of the dye-ssDNA on the GO-functionalized AuNWs, quenching of the dye fluorescence and fluorescence recovery due to release of the dye-ssDNA from the motor surface upon hybridization with the target miRNA (2); fluorescence images of an MCF-7 cell before (3) and after (4) 20 min incubation with the ssDNA@GO-modified AuNWs under a US field (6 V, $2.66 \mathrm{MHz}$ ). Scale bar, $10 \mu \mathrm{m}$. Reproduced and adapted from [58] (a) and [3] (b) with permission. Copyright SAGE Publications, 2019 (a) and ACS, 2015 (b).

Regarding the intracellular delivery of nucleic acids, Wang's group also pioneered to propose gene silencing strategies effective, rapid and compatible with cell viability, using the knockout of green fluorescent protein (GFP) encoding gene as a model. The strategies involved the use of AuNWs wrapped with a rolling circle amplification (RCA) DNA strand, which served to anchor the siRNA therapy (Figure 4a,b) [4] or loaded with the Cas9-sgRNA complex [59]. The AuNWs were modified with a cysteamine SAM and GFP/RCA (Figure 4c) [4] or with a mercaptopropionic acid (MPA) SAM further incubated with cysteine and EDC-NHS and, thereafter, with the Cas9-sgRNA complex [59]. The use of GFP/RCA-wrapped AuNWs allowed the silencing of 94\% of the GFP response in two different cell lines (HEK-293 and MCF-7) after $5 \mathrm{~min}$ as well as a dramatic ( 13-fold) improvement in the silencing response compared to the static modified nanowires (Figure 4d) [4]. Moreover, the Cas9-sgRNA-AuNWs enabled high-efficient knockout with just $0.6 \mathrm{nM}$ of the Cas9-sgRNA complex, displaying more than 80\% GFP-knockout within $2 \mathrm{~h}$ of cell (B16F10) incubation compared to 30\% knockout using their static counterparts (no ultrasound applied). In addition, Cas9-sgRNA-AuNWs exhibited improved cell transfection and faster GFP knockout than that obtained with common lipofectamine-based cell transfection agent [59]. 
a)
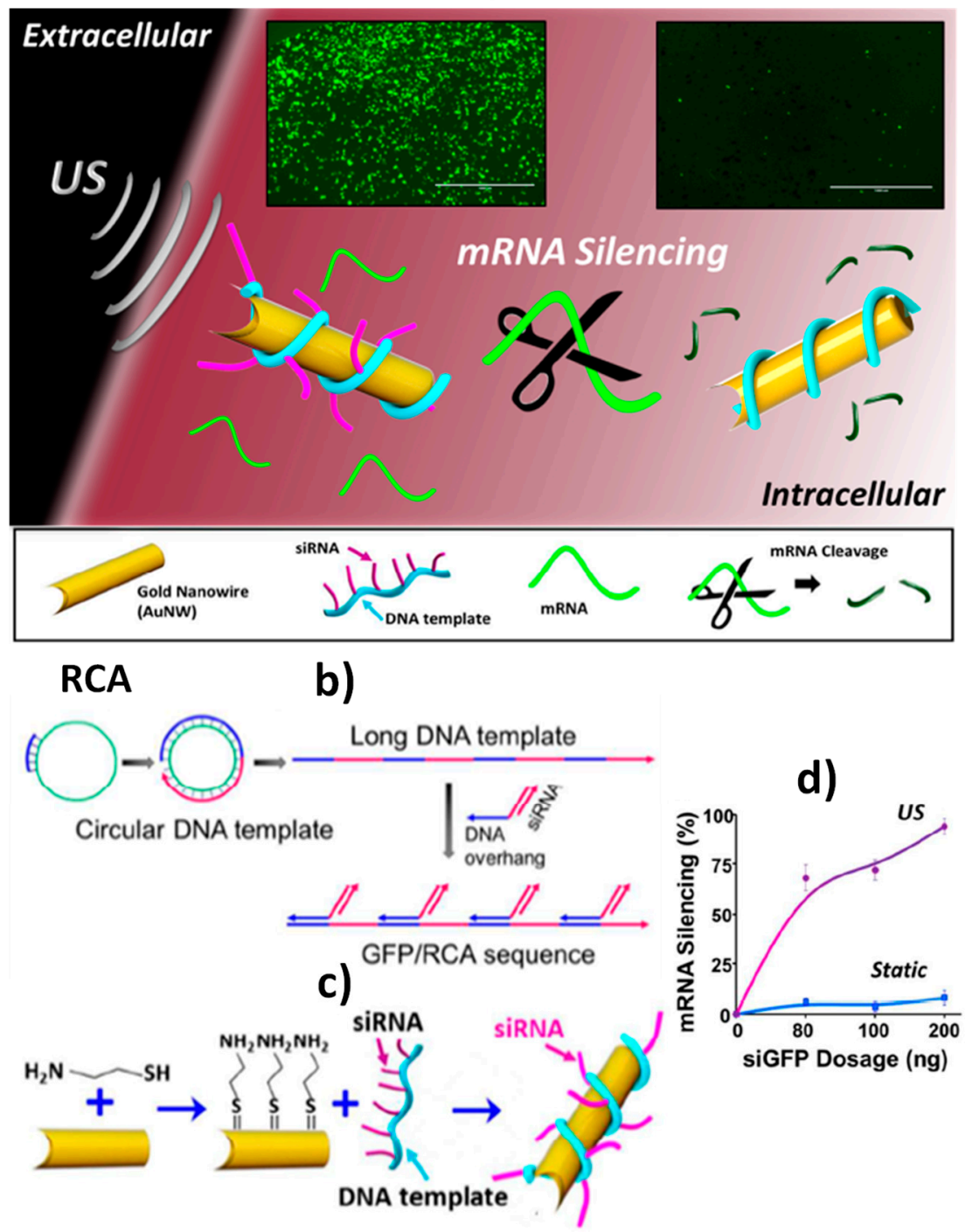

Figure 4. Intracellular delivery of nucleic acids for green fluorescent protein $(G F P)$ gene silencing. Schematic diagrams of: GFP/RCA-AuNW penetration inside a cell due to the nanomotor movement under a US field (a); rolling circle amplification (RCA) methodology to form, from a short DNA sequence and a circular DNA template, a long ssDNA with repeating units subsequently modified with a complementary DNA overhang-siRNA sequence (b); functionalization of the GFP/RCA-AuNWs by cysteamine self-assembly, amine activation and conjugation with GFP/RCA sequence (c); dependence of the efficiency of the gene mRNA silencing inside HEK293-GFP cells, using static and US-propelled GFP/RCA-AuNWs, on the siGFP amount immobilized on AuNWs (d). Reproduced and adapted from [4] with permission. Copyright ACS, 2016. 
Table 1. Optical biosensing or delivery of nucleic acids using functional nanomaterials.

\begin{tabular}{|c|c|c|c|c|c|c|c|c|}
\hline Objective & $\begin{array}{c}\text { Functional } \\
\text { Nanomaterial }\end{array}$ & Rationale Behind the Strategy & $\begin{array}{c}\text { Detection } \\
\text { Technique }\end{array}$ & $\begin{array}{c}\text { Analyte } \\
\text { Detected/Delivered }\end{array}$ & LOD & Sample & Assay Time, min & Ref. \\
\hline Biosensing & $\begin{array}{l}\text { Magnetic Janus } \\
\mathrm{Au}-\mathrm{Ni}-\mathrm{PtNW} \text { s }\end{array}$ & $\begin{array}{c}\text { Increased speed of } \\
\mathrm{Au}-\mathrm{Ni}-\mathrm{PtNW} \text { in the presence } \\
\text { of } \mathrm{Ag}^{+} \text {enriched } \mathrm{H}_{2} \mathrm{O}_{2} \text { solution } \\
\text { generated by performing } \\
\text { sandwich hybridization assays } \\
\text { at photolithography-prepared } \\
\text { 16×AuEs array involving an } \\
\text { AgNPs-labeled detector probe } \\
\text { (AgNPs-Dp) }\end{array}$ & Optical & $\begin{array}{c}\text { DNA and E. coli 16S } \\
\text { mRNA }\end{array}$ & $\begin{array}{l}40 \text { amol synthetic } \\
\text { DNA and } 2000 \\
\text { cfu } \cdot \mathrm{mL}^{-1} \text { of } E \text {. coli }\end{array}$ & Raw bacterial lysate & 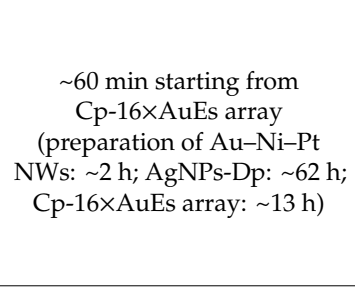 & [56] \\
\hline $\begin{array}{l}\text { Biosensing } \\
\text { (in vitro and } \\
\text { intracellular) }\end{array}$ & GO-AuNWs & $\begin{array}{l}\text { "Off-On" fluorescence } \\
\text { switching due to the } \\
\text { displacement of the } \\
\text { dye-ssDNA probe from the } \\
\text { ssDNA@GO-AuNWs surface } \\
\text { after cell internalization in the } \\
\text { presence of the target miRNA }\end{array}$ & Fluorescent & miRNA-21 & Single cell & $\begin{array}{l}\text { Intact cancer cells } \\
\text { (MCF-7 and HeLa) }\end{array}$ & $\begin{array}{c}\text { 5-10 min starting from } \\
\text { ssDNA@GO-AuNWs } \\
\text { (AuNWs: } \sim 2 \mathrm{~h} \text {; } \\
\text { ssDNA@GO-AuNWs } \sim 14 \mathrm{~h} 15 \\
\text { min) }\end{array}$ & [3] \\
\hline $\begin{array}{l}\text { Biosensing } \\
\text { (in vitro and } \\
\text { intracellular) }\end{array}$ & GO-AuNWs & $\begin{array}{l}\text { "OFF-ON" fluorescence } \\
\text { switching due to the } \\
\text { displacement of the } \\
\text { dye-ssDNA probe from the } \\
\text { ssDNA@GO-AuNWs surface } \\
\text { after cell internalization in the } \\
\text { presence of the target mRNA }\end{array}$ & Fluorescent & $\begin{array}{l}\text { HPV16 E6 mRNA } \\
\text { transcripts }\end{array}$ & Single cell & $\begin{array}{l}\text { Total RNA extracted } \\
\text { from HPV-positive } \\
\text { OPC cells and intact } \\
\text { cells (HPV-positive } \\
\text { or HPV-negative } \\
\text { human OPC cells) }\end{array}$ & $\begin{array}{c}15 \text { min starting from } \\
\text { ssDNA@GO-AuNWs } \\
\text { (AuNWs: } \sim 2 \mathrm{~h} ; \\
\text { ssDNA@GO-AuNWs } \sim 14 \mathrm{~h} \\
15 \mathrm{~min} \text { ) }\end{array}$ & [58] \\
\hline Delivery & $\begin{array}{l}\text { siRNA/RCA- } \\
\text { AuNWs }\end{array}$ & $\begin{array}{l}\text { Intracellular delivery of } \\
\text { GFP/RCA to knockout } \\
\text { GFP gene }\end{array}$ & Fluorescent & siRNA/RCA & Single cell & $\begin{array}{l}\text { Intact HEK-293 and } \\
\text { MCF-7 cells }\end{array}$ & $\begin{array}{c}\sim 5 \mathrm{~min} \text { starting from } \\
\text { siRNA/RCA- AuNWs } \\
\text { (AuNWs: } \sim 2 \mathrm{~h} \text {; RCA: } \sim 19 \mathrm{~h} \\
45 \mathrm{~min} \text {; siRNA/RCA- AuNWs: } \\
\sim 13 \mathrm{~h} \text { ) }\end{array}$ & [4] \\
\hline Delivery & $\begin{array}{l}\text { Cas9-sgRNA- } \\
\text { AuNWs }\end{array}$ & $\begin{array}{l}\text { Intracellular delivery of } \\
\text { Cas9-sgRNA complex to } \\
\text { silence the GFP response }\end{array}$ & Fluorescent & $\begin{array}{l}\text { Cas9-sgRNA } \\
\text { complex }\end{array}$ & Single cell & Intact B16F10 cells & $\begin{array}{c}\sim 5 \text { min starting from } \\
\text { Cas9-sgRNA-AuNWs } \\
\text { (AuNWs: } \sim 2 \text { h; Cas9-sgRNA } \\
\text { complex: } \sim 10 \text { min; } \\
\text { Cas9-sgRNA-AuNWs: } \sim 16 \text { h) }\end{array}$ & [59] \\
\hline
\end{tabular}

cfu: colony forming units; GFP: green fluorescent protein; GO: graphene oxide; HPV: human papillomavirus; OPC: associated oropharyngeal cancer; LOD: limit of detection; RCA: rolling circle amplification. 


\subsection{Electrochemical Biosensing of Nucleic Acids Using Functional Nanomaterials.}

AuNPs, MNPs and Janus NPs have been widely and successfully exploited in the electrochemical biosensing of nucleic acids. Table 2 summarizes the main analytical characteristics of some highlighted methods discussed below.

A very sensitive PCR-free method for electrochemical biosensing of miRNAs has been proposed using AuNPs as anchoring spots for the ruled and tuned immobilization of the capture probes, improving the biorecognition process efficiency [10]. This method is based on the selective recognition of the RNA/miRNA hybrid formed by the direct hybridization of the target miRNA at an AuNPs-screen-printed carbon electrode (SPCE) modified with a thiolated complementary RNA capture probe and $\mathrm{MCH}$ with the viral p19-MBP (maltose binding protein) fusion protein further conjugated with an horseradish peroxidase (HRP)-conjugated anti-MBP antibody. A limit of detection (LOD) of $142 \mathrm{fmol} \mathrm{L}^{-1}$ for the synthetic target miRNA was achieved and the method allowed the determination of the endogenous content of miRNA-21 in just $50 \mathrm{ng}$ of the total RNA extracted from cancerous and healthy cells.

An interesting methodology for the electrochemical detection of Leishmania DNA was reported by de la Escosura-Muñiz et al. [12] combining the advantages of magnetic purification/pre-concentration and the use of AuNPs tags for electrochemical detection at the SPCEs. In this method, isothermal amplification of Leishmania DNA was performed using primers labeled with magnetic beads (MBs) and AuNPs. The double-labeled amplified products (MB-amplified DNA-AuNP complexes) were magnetically collected on SPCEs and the electrocatalytic activity of the AuNPs tags toward the hydrogen evolution reaction, measured by chronoamperometry, allowed the detection of less than one parasite per microliter of blood.

Attractive strategies for the sensitive electrochemical detection of nucleic acids have also been proposed using AuNPs as nanocarriers of redox-labeled DNA probes [14,15], DNA probes and enzymes [13], and redox reporters [15,16]. Wang et al. [14] reported a sandwich hybridization assay at an Au electrode modified with a thiolated capture probe and the use of AuNPs modified with two types of signaling reporter DNAs labeled with methylene blue (where just one was complementary to the target DNA). The methylene blue signal, measured by differential pulse voltammetry (DPV), enabled the detection of the target DNA in a wide linear range $\left(10^{-13}\right.$ to $\left.10^{-8} \mathrm{M}\right)$ with a LOD as low as $50 \mathrm{fM}$. The use of the non-complementary signaling reporter DNA diluted the reporter probe layer on the AuNPs, thereby reducing the cross-reaction of the functionalized AuNPs and improving the achieved LOD by 20 times.

Wan et al. [13] described a detection scheme where the target DNA helped the setup of sandwich complexes between electrode-immobilized capture probes and reporter probe-linked AuNPs. The terminal desoxynucleotidyl transferase (TdT)-catalyzed elongation of the free $3^{\prime}$-terminal of DNA on the AuNPs led to the incorporation of multiple biotin moieties into the generated long DNA strands, which were further used for conjugating avidin-modified HRP molecules (Figure 5a). Using amperometric detection in the presence of 3,3',5,5'-tetramethylbenzidine (TMB)/ $\mathrm{H}_{2} \mathrm{O}_{2}$, the method provided an LOD of $10 \mathrm{fM}$.

Wang et al. [15] reported a reagent-less strategy for DNA biosensing by exploiting the structure change of electrode-immobilized hairpin DNA probes after hybridization and the subsequent electrochemical signal modification of redox-tagged AuNPs attached to the free end of the hairpin probes. This strategy used AuNPs as nanocarriers with elevated conductivity and surface area for the immobilization of many redox-active melamine- $\mathrm{Cu}^{2+}$ complexes, and enabled the DPV detection of the target DNA down to $1.2 \times 10^{-19} \mathrm{M}$. The method was applied to DNA determination in $10 \%$ of the spiked human serum samples.

Recently, an enzyme-less sandwich hybridization-based electrochemical biosensor for the determination of miRNAs has been reported [16]. The method made use, for the first time, of SPCEs modified with nanohybrids of rGO with AuNPs as scaffolds to immobilize a thiolated DNA capture probe, as well as of ferrocene $(\mathrm{Fc})$ capped AuNPs modified with streptavidin as non-enzymatic 
tracers to conjugate the biotinylated DNA detector probe. DPV transduction using Fc as redox reporter was employed. The biosensor exhibited a high sensitivity for the detection of synthetic target miRNA-21 (LOD of $5 \mathrm{fM}$ ) and selectivity (single nucleotide discrimination). In addition, it was successfully employed to perform the accurate determination of miRNA-21 in a small amount of cellular RNA (50 ng) and directly in scarcely diluted serum samples from breast cancer patients.

Yang et al. [17] exploited the use of AuNPs without further functionalization as electron transfer regulators to develop a simple but sensitive electrochemical DNA biosensor. An enhancement of the interfacial electron transfer between the electrode and the redox couple $\left(\left[\mathrm{Fe}(\mathrm{CN})_{6}\right]^{3-/ 4-}\right)$ in the solution was observed in the absence of the target DNA, due to the AuNPs serving as conductive bridges over the non-covalent interaction of AuNPs with electrode-immobilized ssDNA probes (Figure 5b). On the contrary, hybridization of the target miRNA with the ssDNA probe hindered the AuNPs-DNA interaction and the consequent enhancement in the electron transfer process. By monitoring changes by electrochemical impedance spectroscopy (EIS), the target DNA, related with the BRCA1 breast cancer gene, was detected down to $1 \mathrm{pM}$.
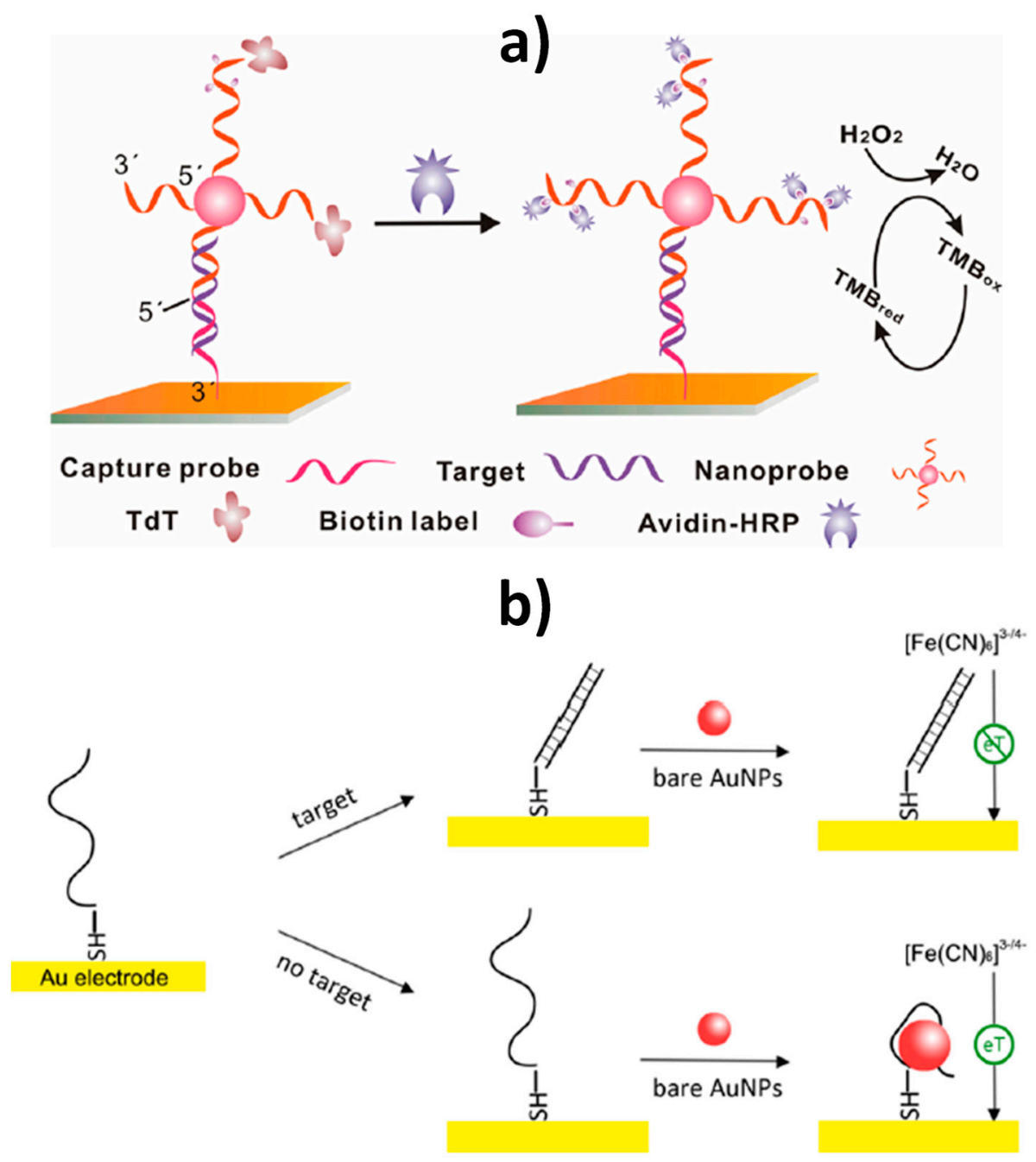

Figure 5. Electrochemical biosensing of nucleic acids based on the use of AuNPs as nanocarriers of probes further elongated with TdT to generate long DNA strands bearing multiple biotin moieties, further conjugated with avidin-HRP complex (a), and electron transfer regulators through their non-covalent interaction with ssDNA (b). Reprinted from [13] (a) and [17] (b) with permission. Copyrights ACS, 2015 (a) and ACS, 2014 (b). 
MNPs have been used mainly as nanosupports in the electrochemical biosensing of nucleic acids. Altay et al. [60] reported a direct hybridization method using a DNA capture probe immobilized on amino functionalized carbon coated magnetic nanoparticles ( $\mathrm{NH}_{2}$-CC-MNPs). The method was applied to determine a synthetic DNA sequence characteristic of the Hepatitis B virus (HBV) by measuring the guanine oxidation signal using DPV and showing a linear range between 5 and $25 \mu \mathrm{gL} \mathrm{m}^{-1}$ and an LOD of $1.15 \mu \mathrm{g} \mathrm{mL} \mathrm{m}^{-1}$ (20 pmol in $110 \mu \mathrm{L}$ solution).

$\mathrm{Fe}_{3} \mathrm{O}_{4} @ \mathrm{Au}$ MNPs have been used as nanosupports for the implementation of sandwich-type hybridization assays for the detection of genetically modified organisms (GMOs). $\mathrm{Fe}_{3} \mathrm{O}_{4} @ \mathrm{Au} \mathrm{MNPs}$ were synthesized using a two-step procedure consisting of the $\mathrm{Fe}_{3} \mathrm{O}_{4}$ MNPs synthesis by thermal decomposition, followed by coating with a gold shell via chemical reduction of $\mathrm{Au}$ (III) in the presence of a reducing capping agent (oleylamine). The methods involved covalent immobilization of DNA capture probes modified with amino groups $\left(\mathrm{NH}_{2}-\mathrm{Cps}\right)$ through EDC-NHS chemistry on the surface of $\mathrm{Fe}_{3} \mathrm{O}_{4} @ \mathrm{Au}$ MNPs modified with SAMs prepared from different mercaptoacids such as thioctic acid (TOA) [18] or 6-mercaptohexanoic acid (MHA) [29,30,61] with [18,30,61] or without [29] post-treatment with $\mathrm{MCH}$ (Figure 6a). The detector probes (Dps) were tagged with fluorescein isothiocyanate (FITC) and digoxigenin (DIG) and then with Fab fragments of antibodies specific to those tags conjugated to HRP. In all cases, the detection was performed by chronoamperometry using the TMB- $\mathrm{H}_{2} \mathrm{O}_{2}$ system after the magnetic capture of the modified MNPs on the surface of commercial SPCEs $[18,29,30]$ or homemade gold [61] electrodes (Figure 6b). These methods provide LODs in the $\mathrm{pM}-\mathrm{nM}$ range for the synthetic DNA sequence, reliability for single $[18,29,61]$ or dual [30] determination, and were applied to the detection of genetic modified soybean and maize events in PCR amplicons from certified reference materials [18], in cat feed, soybean seeds and maize flour samples [29,61]. It is also worth remarking that while the assay time starting from $\mathrm{Cp}-\mathrm{Fe}_{3} \mathrm{O}_{4} @ \mathrm{Au} \mathrm{MNPs}$ is $\sim 2 \mathrm{~h}$, the synthesis of the $\mathrm{Fe}_{3} \mathrm{O}_{4} @ \mathrm{Au}$ MNPs requires $\sim 20 \mathrm{~h}$ and their modification with the SAM and $\mathrm{Cp} \sim 24$ and $2 \mathrm{~h}$, respectively.

Janus Au-mesoporous silica nanoparticles (Au-MS JNPs) were previously exploited as scaffolds to design integrated electrochemical enzymatic biosensors [47,48]. Recently, they have also been used as labels for signal amplification in the electrochemical aptasensing of carcinoembryonic antigen (CEA) [49]. The strategy involved proper functionalization of Janus nanoparticles silica surfaces with HRP to act as signaling element while the $\mathrm{Au}$ face was modified with a dual biotin thiol-functionalized anti-CEA DNA hairpin aptamer (Figure 7a top). The specific recognition of CEA by the bi-functionalized Janus nanoparticles provoked unfolding of the hairpin aptamer, thus unmasking the biotin residues and allowing the recognition of the CEA-Janus nanoparticle complex by avidin-modified $\mathrm{Fe}_{3} \mathrm{O}_{4} @ \mathrm{SiO}_{2}$ NanoCaptors ${ }^{\circledR}$ (NCR-80). This resulted in an enhanced amperometric signal in the presence of $\mathrm{H}_{2} \mathrm{O}_{2} / \mathrm{HQ}$ (hydroquinone) upon their magnetic capture on the working electrode of SPCEs (Figure 7a down). This aptasensor was able to detect CEA in the range from $5.5 \mathrm{pM}$ to $28 \mathrm{nM}$, with a LOD of $1.2 \mathrm{pM}$ and was applied to the analysis of spiked lyophilized human serum [49]. A closely related method has been proposed recently by the same group using mesoporous silica nanoparticles (MSNs) loaded with the redox probe methylene blue and capped with an avidin-imminobiotin (Av-ImB) stimulus-responsive gate-like ensemble (Figure $7 \mathrm{~b}$ top) as the signal amplification element in connection with an aptasensor for CEA constructed by attaching a biotin and thiol-functionalized anti-CEA DNA hairpin aptamer on AuNPs-SPCEs [50]. In this case, the unfolding of the aptamer molecule attached to the AuNPs-SPCE after CEA specific recognition leaves biotin residues free to further associate with the avidin-capped mesoporous nanocarrier (Figure $7 \mathrm{~b}$ down). By DPV measurement of the acid-assisted released encapsulated methylene blue, CEA could be determined over the $1.0 \mathrm{pg} \mathrm{mL}^{-1}$ to $160 \mathrm{ng} \mathrm{mL}^{-1}$ range in five-fold diluted human serum samples. 


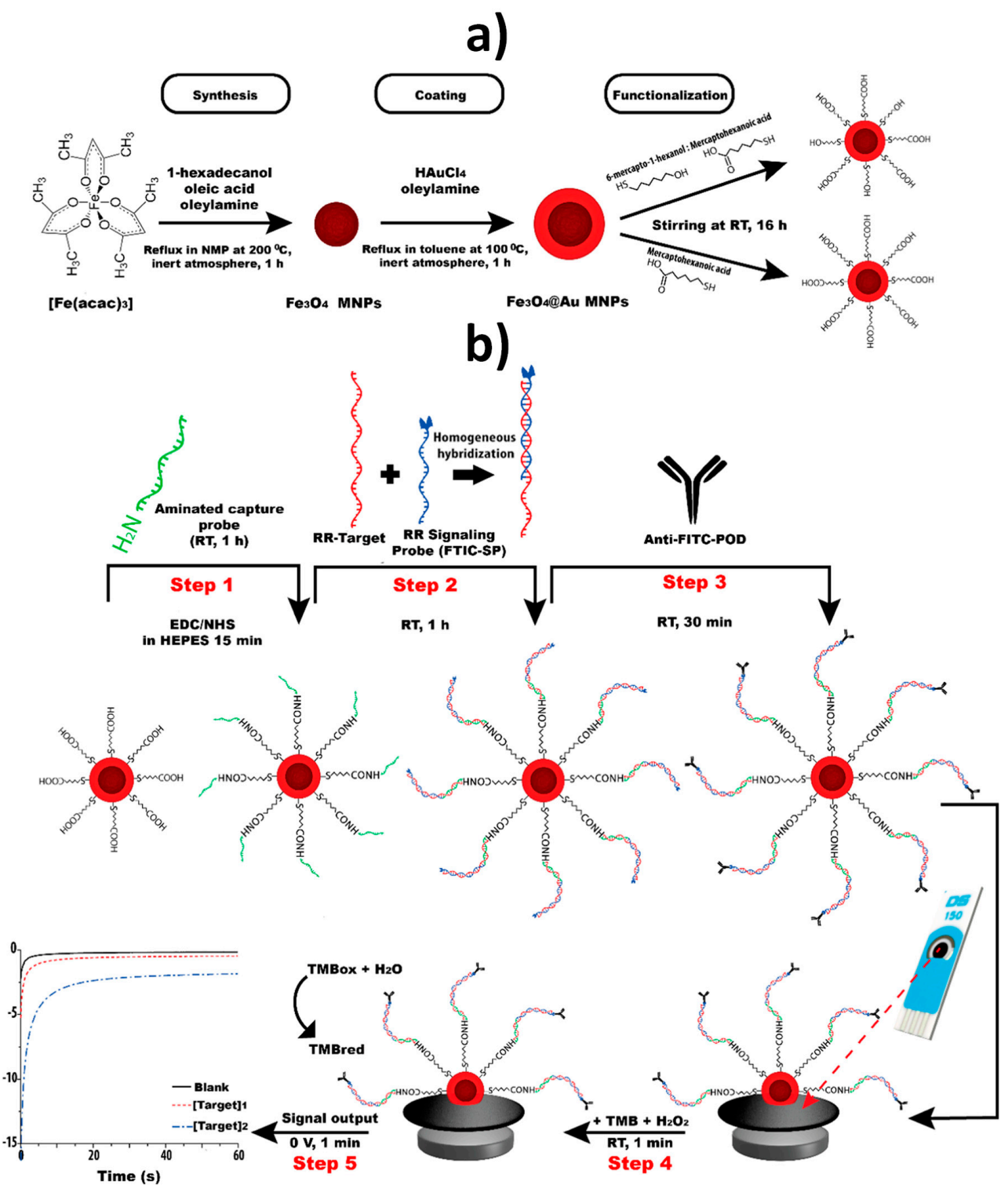

Figure 6. Schematic illustration of an electrochemical biosensing strategy for detecting glyphosate-tolerant soybean, GTS 40-3-2, by implementing a sandwich hybridization format onto $\mathrm{Fe}_{3} \mathrm{O}_{4} @ \mathrm{Au}$ MNPs nanosupports. Synthesis and modification of core-shell $\mathrm{Fe}_{3} \mathrm{O}_{4} @ \mathrm{Au} \mathrm{MNPs}$ with a MHA/MCH SAM (a). Involved protocol comprised (b): covalent immobilization of the $\mathrm{NH}_{2}-\mathrm{Cp}$ to the MHA/MCH-modified- $\mathrm{Fe}_{3} \mathrm{O}_{4} @ \mathrm{Au} \mathrm{MNPs}$ through the EDC-NHS reaction (1); homogeneous hybridization between the FITC-modified Dp and the target DNA sequence, and subsequent heterogeneous hybridization reaction with $\mathrm{NH}_{2}-\mathrm{Cp}-\mathrm{MHA} / \mathrm{MCH}-$ modified- $\mathrm{Fe}_{3} \mathrm{O}_{4} @ \mathrm{Au} \mathrm{MNPs}$ (2); enzymatic labelling with HRP-antiFITC Fab fragments (3); and chronoamperometric detection using the TMB- $\mathrm{H}_{2} \mathrm{O}_{2}$ system at SPCEs upon magnetic capture of the modified MNPs on the working electrode (4) and (5). Reprinted from [29] with permission. Copyright Elsevier, 2018. 

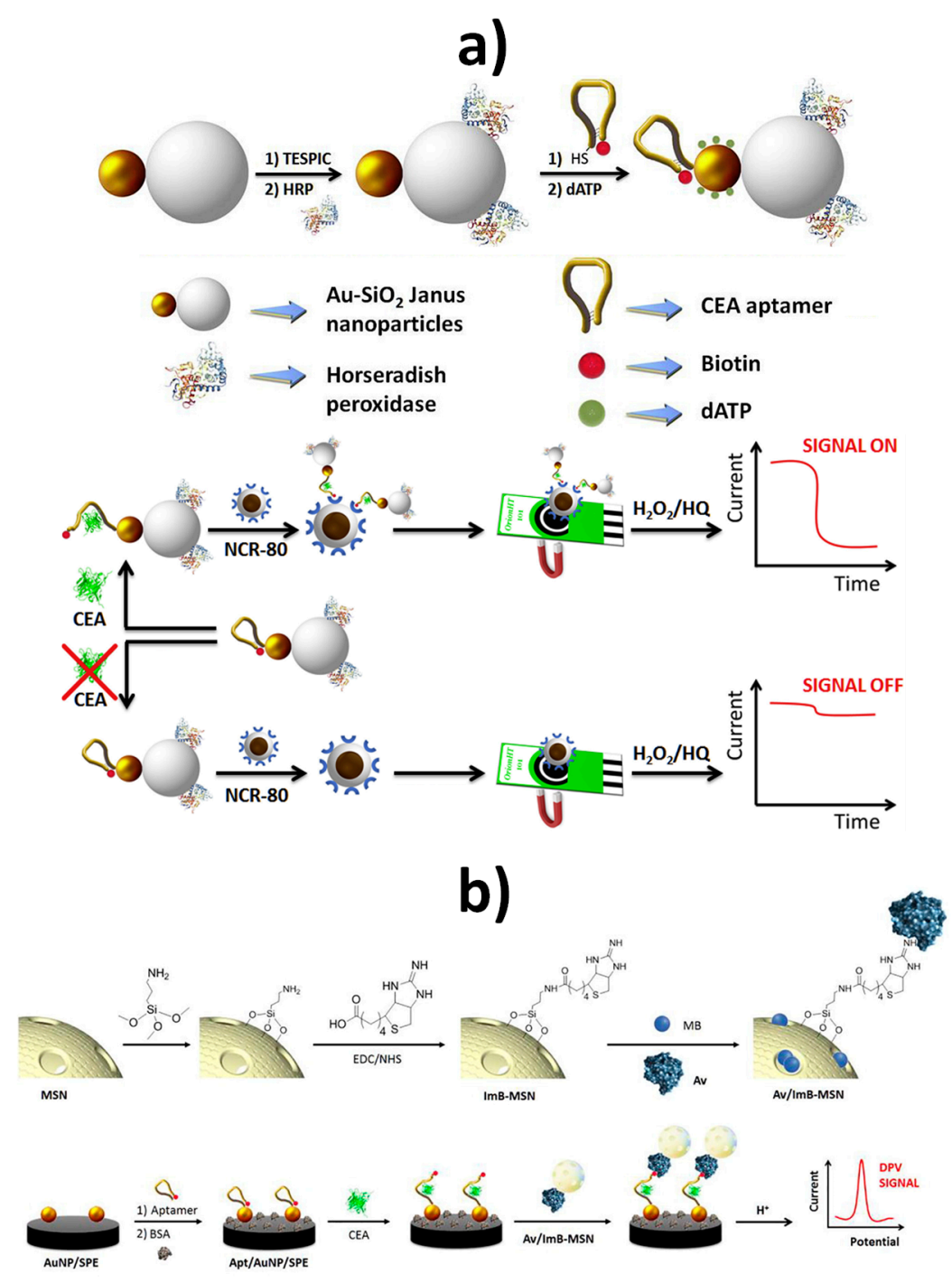

Figure 7. Electrochemical aptasensing of CEA involving the use of Janus Au-mesoporous silica nanoparticles (a) and mesoporous silica nanoparticles (b) as nanolabels or nanocarriers of signaling elements, respectively. Schematic display of the protocols used to functionalize the nanoparticles (top) and their use for electrochemical CEA aptasensing (down). Reprinted and adapted from [49] (a) and [50] (b) with permission. Copyrights Elsevier, 2019 (a,b). 
Table 2. Electrochemical biosensing of nucleic acids using functional nanomaterials

\begin{tabular}{|c|c|c|c|c|c|c|c|c|c|}
\hline Electrode & $\begin{array}{c}\text { Functional } \\
\text { Nanomaterial (Role) }\end{array}$ & Method & Detection Technique & Target Analyte & Linear Range & LOD & Sample & Assay Time, Min & Ref. \\
\hline AuNPs-SPCE & $\begin{array}{l}\text { AuNPs (electrode } \\
\text { modifier) }\end{array}$ & $\begin{array}{l}\text { Direct hybridization approach at } \\
\text { SH-RNA-Cp/MCH-AuNPs-SPCE } \\
\text { and selective recognition of the } \\
\text { RNA/miRNA hybrid with the } \\
\text { p19-MBP fusion protein further } \\
\text { conjugated with and HRP } \\
\text { anti-MBP antibody }\end{array}$ & $\begin{array}{c}\text { Amperometry } \\
\left(\mathrm{H}_{2} \mathrm{O}_{2} / \mathrm{HQ}\right)\end{array}$ & miRNA-21 & $\begin{array}{l}0.5-50 \\
\mathrm{pmol} \cdot \mathrm{L}^{-1}\end{array}$ & $142 \mathrm{fmol} \cdot \mathrm{L}^{-1}$ & $\begin{array}{c}\mathrm{RNA}_{\mathrm{t}} \text { extracted } \\
\text { from healthy and } \\
\text { cancerous breast } \\
\text { cells }\end{array}$ & $\begin{array}{l}\sim 60 \text { min starting from } \\
\text { SH-RNA-Cp/MCH-AuNPs-SPCE } \\
\text { (SPCE modification: } \sim 9 \mathrm{~h} 5 \mathrm{~min} \text { ) }\end{array}$ & [10] \\
\hline SPCE & $\begin{array}{l}\text { AuNPs (catalytic } \\
\text { label) }\end{array}$ & $\begin{array}{l}\text { Isothermal amplification of } \\
\text { Leishmania DNA using primers } \\
\text { labeled with MBs and AuNPs } \\
\text { and magnetic capture of the } \\
\text { MB-amplified DNA-AuNP } \\
\text { complexes on SPCEs }\end{array}$ & Chronoamperometry & Leishmania DNA & $\begin{array}{l}500-0.5 \\
\text { parasite } \mathrm{mL}^{-1} \\
\text { blood }\end{array}$ & $\begin{array}{l}0.8 \text { parasite } \\
\mathrm{mL}^{-1} \text { blood }\end{array}$ & Dog's blood & $\begin{array}{c}\sim 10 \text { min starting from primers } \\
\text { conjugated with MBs and } \\
\text { AuNPs (primers conjugation: } \\
\sim 65 \mathrm{~h} 55 \text { min) }\end{array}$ & [12] \\
\hline $\mathrm{AuE}$ & $\begin{array}{l}\text { AuNPs (nanocarriers } \\
\text { of redox-labeled } \\
\text { DNA probes) }\end{array}$ & $\begin{array}{l}\text { Sandwich hybridization assay } \\
\text { developed at an Au electrode } \\
\text { modified with thiolated Cps; use } \\
\text { of AuNPs modified with two } \\
\text { different probes labeled with } \\
\text { methylene blue (just one } \\
\text { complementary to the target } \\
\text { DNA) }\end{array}$ & $\begin{array}{l}\text { DPV (methylene } \\
\text { blue) }\end{array}$ & Target DNA & $10^{-13}-10^{-8} \mathrm{M}$ & $50 \mathrm{fM}$ & - & $\begin{array}{l}\sim 2 \mathrm{~h} \text { starting from } \\
\text { SH-Cp/MCH-AuE (modified } \\
\text { AuE: } 1 \mathrm{~h} \text { and DNA-AuNPs } \\
\text { conjugates: } \sim 5 \mathrm{~h} 30 \mathrm{~min} \text { ) }\end{array}$ & [14] \\
\hline $\mathrm{AuE}$ & $\begin{array}{l}\text { AuNPs (nanocarriers } \\
\text { of reporter probes } \\
\text { and enzymes) }\end{array}$ & $\begin{array}{l}\text { Sandwich hybridization between } \\
\text { SH-Cp/SH-OEG-AuE and } \\
\text { reporter probe-linked AuNPs, } \\
\text { and terminal deoxynucleotidyl } \\
\text { transferase (TdT)-catalyzed } \\
\text { elongation of the free 3'-terminal } \\
\text { of DNA on the nanoprobe to } \\
\text { incorporate multiple biotin } \\
\text { moieties further conjugated with } \\
\text { avidin-modified HRP molecules }\end{array}$ & $\begin{array}{l}\text { Amperometry } \\
\left(\mathrm{TMB} / \mathrm{H}_{2} \mathrm{O}_{2}\right)\end{array}$ & Target DNA & $10 \mathrm{fM}-10 \mathrm{pM}$ & $10 \mathrm{fM}$ & - & $\begin{array}{l}\sim 2 \mathrm{~h} 45 \mathrm{~min} \text { starting from } \\
\text { SH-Cp/SH-OEG-AuE (modified } \\
\text { AuE: } \sim 16 \mathrm{~h} \text { and DNA-AuNPs } \\
\text { conjugates: } \sim 56 \mathrm{~h} 15 \mathrm{~min} \text { ) }\end{array}$ & [13] \\
\hline $\mathrm{AuE}$ & $\begin{array}{c}\text { AuNPs (nanocarriers } \\
\text { of melamine--Cu }{ }^{2+} \\
\text { complexes) }\end{array}$ & $\begin{array}{c}\text { Hybridization-induced } \\
\text { structural variation of } \\
\text { electrode-immobilized SH-hCp } \\
\text { with attached } \mathrm{Cu}^{++} \text {-Mel-AuNPs }\end{array}$ & $\operatorname{DPV}\left(\mathrm{Cu}^{2+} / \mathrm{Cu}^{+}\right)$ & Target DNA & $\begin{array}{c}1.0 \times 10^{-18} \\
\mathrm{M}-1.0 \times 10^{-12} \\
\mathrm{M}\end{array}$ & $1.2 \times 10^{-19} \mathrm{M}$ & $\begin{array}{l}10 \% \text { spiked human } \\
\text { serum }\end{array}$ & $\begin{array}{c}\sim 40 \text { min starting from } \\
\mathrm{Cu}^{2+}-\mathrm{Mel}-\mathrm{AuNPs} / \mathrm{SH}-\mathrm{hCp} / \mathrm{MCH} / \\
\text { AuE (AuE modification: } \sim 77 \mathrm{~h} \\
20 \mathrm{~min} \text { ) }\end{array}$ & [15] \\
\hline $\mathrm{AuNPs} / \mathrm{rGO} / \mathrm{SPCEs}$ & $\begin{array}{l}\text { AuNPs (nanocarriers } \\
\text { of Strep and Fc) }\end{array}$ & $\begin{array}{c}\text { Sandwich hybridization } \\
\text { approach at a } \\
\text { MCH/HS-DNACp-AuNPs/rGO/ } \\
\text { SPCEs using a biotinylated Dp } \\
\text { conjugated with Fc-AuNPs-Strep } \\
\text { conjugates }\end{array}$ & $\operatorname{DPV}(\mathrm{Fc})$ & miRNA-21 & $10 \mathrm{fM}-2 \mathrm{pM}$ & $5 \mathrm{fM}$ & $\begin{array}{l}\mathrm{RNA}_{\mathrm{t}} \text {, extracted } \\
\text { from breast } \\
\text { adenocarcinoma } \\
\text { cells and serum } \\
\text { from cancer } \\
\text { patients }\end{array}$ & $\begin{array}{c}\sim 1 \mathrm{~h} 45 \mathrm{~min} \text { starting from } \\
\text { Fc-AuNPs-Strep (AuNPs } \\
\text { modification: } \sim 24 \mathrm{~h} \text { and } \\
\text { HS-DNACp-AuNPs/rGO/SPCE: } \\
\sim 9 \mathrm{~h} 30 \mathrm{~min} \text { ) }\end{array}$ & [16] \\
\hline
\end{tabular}


Table 2. Cont.

\begin{tabular}{|c|c|c|c|c|c|c|c|c|c|}
\hline Electrode & $\begin{array}{c}\text { Functional } \\
\text { Nanomaterial (Role) }\end{array}$ & Method & Detection Technique & Target Analyte & Linear Range & LOD & Sample & Assay Time, Min & Ref. \\
\hline AuE & $\begin{array}{l}\text { AuNPs (electron } \\
\text { transfer regulator) }\end{array}$ & $\begin{array}{l}\text { Enhancement of the interfacial } \\
\text { electron transfer process } \\
\text { between the electrode and the } \\
\text { redox couple }\left(\left[\mathrm{Fe}(\mathrm{CN})_{6}\right]^{3-1 / 4-}\right) \text { in } \\
\text { the absence of target DNA due to } \\
\text { AuNPs-DNA binding }\end{array}$ & $\operatorname{EIS}\left(\left[\mathrm{Fe}(\mathrm{CN})_{6}\right]^{3-/ 4-}\right)$ & $\begin{array}{c}\text { Target DNA } \\
\text { (BRCA1 gene) }\end{array}$ & $1 \mathrm{pM}-500 \mathrm{nM}$ & $1 \mathrm{pM}$ & - & $\begin{array}{l}\sim 2 \mathrm{~h} \text { starting from AuNPs } \\
\text { (AuNPs preparation: } \sim 30 \mathrm{~min} \\
\text { and HS-DNACP-AuE: } \sim 3 \mathrm{~h} \text { ) }\end{array}$ & [17] \\
\hline PGE & $\mathrm{NH}_{2}$-CC-MNPs & $\begin{array}{l}\text { Direct DNA hybridization at } \\
\text { DNA Cp immobilized onto } \\
\mathrm{NH}_{2} \text {-CC-MNPs }\end{array}$ & $\begin{array}{l}\text { DPV (guanine } \\
\text { oxidation) }\end{array}$ & HBV target DNA & $5-25 \mu \mathrm{g} \mathrm{mL}^{-1}$ & $1.15 \mu \mathrm{g} \mathrm{mL}^{-1}$ & - & $\begin{array}{c}\sim 35 \mathrm{~min} \text { starting from } \\
\text { Cp-NH } \mathrm{NH}_{2} \text {-CC-MNPs (synthesis: } \\
\sim 23 \mathrm{~h} 30 \mathrm{~min}+\mathrm{Cp} \\
\text { immobilization: } \sim 1 \mathrm{~h} 20 \mathrm{~min} \text { ) }\end{array}$ & [60] \\
\hline SPCE & $\mathrm{Fe}_{3} \mathrm{O}_{4} @ \mathrm{Au} \mathrm{MNPs}$ & $\begin{array}{c}\text { Sandwich hybridization } \\
\text { approach involving covalent } \\
\text { immobilization of an } \mathrm{NH}_{2} \text {-DNA } \\
\text { Cp onto } \mathrm{Fe}_{3} \mathrm{O}_{4} @ \mathrm{Au} \mathrm{MNPs} \\
\text { modified with a TOA/MCH } \\
\text { SAM and a FITC signaling probe } \\
\text { further conjugated with } \\
\text { anti-FITC-HRP Fab fragment }\end{array}$ & $\begin{array}{l}\text { Chronoamperometry } \\
\left(\mathrm{TMB} / \mathrm{H}_{2} \mathrm{O}_{2}\right)\end{array}$ & $\begin{array}{l}\text { GMO (a specific } \\
\text { fragment of the } \\
\text { transgenic construct } \\
\text { from maize } \\
\text { MON810 maize) }\end{array}$ & $0.25-2.5 \mathrm{nM}$ & $0.15 \mathrm{nM}$ & $\begin{array}{l}\text { PCR amplicons } \\
\text { obtained from } \\
\text { CRMs of maize } \\
\text { MON810 }\end{array}$ & $\begin{array}{l}\sim 2 \mathrm{~h} \text { starting from } \mathrm{Cp}^{-} \mathrm{Fe}_{3} \mathrm{O}_{4} @ \mathrm{Au} \\
\text { MNPs (MNPs synthesis: } \sim 20 \\
\text { h;TOA/MCH SAM: } 24 \mathrm{~h} ; \mathrm{Cp} \\
\text { immobilization: } \sim 2 \mathrm{~h} \text { ) }\end{array}$ & [18] \\
\hline SPCE & $\mathrm{Fe}_{3} \mathrm{O}_{4} @ \mathrm{Au} \mathrm{MNPs}$ & $\begin{array}{c}\text { Sandwich hybridization } \\
\text { approach involving covalent } \\
\text { immobilization of an } \mathrm{NH}_{2} \text {-DNA } \\
\text { Cp onto } \mathrm{Fe}_{3} \mathrm{O}_{4} @ \mathrm{QAu} \mathrm{MNPs} \\
\text { modified with a MHA/MCH } \\
\text { SAM and a FITC signaling probe } \\
\text { further conjugated with } \\
\text { anti-FITC-HRP Fab fragment }\end{array}$ & $\begin{array}{l}\text { Chronoamperometry } \\
\left(\mathrm{TMB} / \mathrm{H}_{2} \mathrm{O}_{2}\right)\end{array}$ & $\begin{array}{l}\text { DNA fragments } \\
\text { from the insertion } \\
\text { point of the } \\
\text { transgenic construct } \\
\text { of RR GTS 40-3-2 } \\
\text { soybean, an } \\
\text { event-specific } \\
\text { sequence, and of } \\
\text { the taxon-specific } \\
\text { soybean gene, lectin }\end{array}$ & $\begin{array}{c}0.1-10.0 \mathrm{nM} \\
\text { (event specific) } \\
0.1-5.0 \mathrm{nM} \\
\text { (taxon-specific) }\end{array}$ & $\begin{array}{c}0.02 \mathrm{nM} \\
\text { (event specific) } \\
0.05 \mathrm{nM} \\
\text { (taxon-specific) }\end{array}$ & $\begin{array}{l}\text { PCR amplicons } \\
\text { obtained from } \\
\text { soybean seeds and } \\
\text { cat feed }\end{array}$ & $\begin{array}{l}\sim 1 \mathrm{~h} 40 \text { min starting from Cp- } \\
\mathrm{Fe}_{3} \mathrm{O}_{4} @ \mathrm{Au} \text { MNPs (synthesis: } \\
\sim 21 \mathrm{~h} \text {; MHAMCH } \\
\mathrm{Cp} \text { immobilization: } \sim 1 \mathrm{~h}: \sim 16 \mathrm{hin} \text {; }\end{array}$ & [29] \\
\hline SPdCE & $\mathrm{Fe}_{3} \mathrm{O}_{4} @ \mathrm{Au} \mathrm{MNPs}$ & $\begin{array}{c}\text { Sandwich hybridization } \\
\text { approaches involving covalent } \\
\text { immobilization of } \mathrm{NH}_{2} \text {-DNA } \\
\text { capture probes onto } \mathrm{Fe}_{3} \mathrm{O}_{4} @ A u \\
\text { MNPs modified with a MHA } \\
\text { SAM and FITC or DIG signaling } \\
\text { probes further conjugated with } \\
\text { anti-FITC-HRP or anti-DIG-HRP } \\
\text { Fab fragments }\end{array}$ & $\begin{array}{l}\text { Chronoamperometry } \\
\left(\mathrm{TMB} / \mathrm{H}_{2} \mathrm{O}_{2}\right)\end{array}$ & $\begin{array}{l}\text { GMO (fragments of } \\
\text { the transgenic } \\
\text { construct from GTS } \\
40-3-2 \text { and } \\
\text { MON89788 } \\
\text { soybean lines) }\end{array}$ & $\begin{array}{l}0.1-2.5 \mathrm{nM} \\
(\mathrm{GTS} 40-3-2) \\
0.1-1.0 \mathrm{nM} \\
(\mathrm{MON} 89788)\end{array}$ & $\begin{array}{l}0.1 \mathrm{nM} \text { (both } \\
\text { events) }\end{array}$ & - & $\begin{array}{l}\sim 2 \mathrm{~h} 5 \mathrm{~min} \text { starting from Cp- } \\
\mathrm{Fe}_{3} \mathrm{O}_{4} @ A u \text { MNPs (synthesis: } \\
\sim 21 \mathrm{~h} ; \mathrm{MHA} \text { MAM: } \sim 16 \mathrm{~h} ; \mathrm{Cp} \\
\text { immobilization: } \sim 1 \mathrm{~h} 35 \mathrm{~min} \text { ) }\end{array}$ & [30] \\
\hline
\end{tabular}


Table 2. Cont

\begin{tabular}{|c|c|c|c|c|c|c|c|c|c|}
\hline Electrode & $\begin{array}{c}\text { Functional } \\
\text { Nanomaterial (Role) }\end{array}$ & Method & Detection Technique & Target Analyte & Linear Range & LOD & Sample & Assay Time, Min & Ref. \\
\hline Homemade AuE & $\mathrm{Fe}_{3} \mathrm{O}_{4} @ \mathrm{Au} \mathrm{MNPs}$ & $\begin{array}{c}\text { Sandwich hybridization } \\
\text { approach involving covalent } \\
\text { immobilization of an } \mathrm{NH}_{2} \text {-DNA } \\
\text { Cp onto } \mathrm{Fe}_{3} \mathrm{O}_{4} @ \text { @u MNPs } \\
\text { modified with a MHA/MCH } \\
\text { SAM and a FITC signaling probe } \\
\text { further conjugated with } \\
\text { anti-FITC-HRP Fab fragment }\end{array}$ & $\begin{array}{l}\text { Chronoamperometry } \\
\quad\left(\mathrm{TMB}-\mathrm{H}_{2} \mathrm{O}_{2}\right)\end{array}$ & $\begin{array}{c}\text { Maize } \\
\text { taxon-specific } \\
\text { (HMGA gene) }\end{array}$ & $0.5-5 \mathrm{nM}$ & $90 \mathrm{pM}$ & $\begin{array}{l}\text { PCR amplicons } \\
\text { obtained from } \\
\text { maize flour }\end{array}$ & 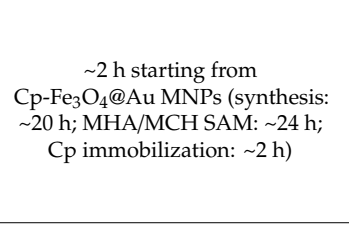 & [61] \\
\hline SPCE & Au-MSN JNPs & $\begin{array}{l}\text { Au-MS JNPs functionalized with } \\
\text { HRP and a dual biotin } \\
\text { thiol-functionalized anti-CEA } \\
\text { DNA hairpin aptamer in } \\
\text { connection with avidin-modified } \\
\mathrm{Fe}_{3} \mathrm{O}_{4} @ \mathrm{SSO}_{2} \text { NanoCaptors }\end{array}$ & $\begin{array}{l}\text { Amperometry } \\
\left(\mathrm{H}_{2} \mathrm{O}_{2} / \mathrm{HQ}\right)\end{array}$ & CEA & $5.5 \mathrm{pM}-28 \mathrm{nM}$ & $1.2 \mathrm{pM}$ & $\begin{array}{l}\text { Spiked lyophilized } \\
\text { human serum } \\
\text { samples }\end{array}$ & $\begin{array}{c}\sim 1 \mathrm{~h} \text { starting from } \\
\text { bifunctionalized Au-MSN JNPs } \\
\text { (synthesis of Au-MSN JNPs: } \\
\sim 38 \mathrm{~h} 30 \text { min; bifunctionalization: } \\
\sim 4 \mathrm{~h} 5 \mathrm{~min} \text { ) }\end{array}$ & [49] \\
\hline AuNPs-SPCE & MSNs & $\begin{array}{l}\text { MSNs loaded with methylene } \\
\text { blue molecules and capped with } \\
\text { an avidin/imminobiotin } \\
\text { stimulus-responsive gate-like } \\
\text { ensemble in connection with an } \\
\text { AuNPs-SPCE modified with a } \\
\text { biotin and thiol-functionalized } \\
\text { anti-CEA DNA hairpin } \\
\text { (Apt-AuNPs-SPCE) }\end{array}$ & $\begin{array}{l}\text { DPV (methylene } \\
\text { blue) }\end{array}$ & CEA & $\begin{array}{c}1.0 \mathrm{pg} \\
\mathrm{mL}^{-1}-160 \mathrm{ng} \\
\mathrm{mL}^{-1}\end{array}$ & $280 \mathrm{fg} \mathrm{mL}^{-1}$ & $\begin{array}{l}\text { 5-fold diluted } \\
\text { human serum } \\
\text { samples }\end{array}$ & $\begin{array}{l}\sim 45 \text { min starting from } \\
\text { bifunctionalized MSNs and } \\
\text { Apt-AuNPs-SPCE (MSNs: } \sim 2 \mathrm{~h} \\
5 \mathrm{~min} \text {; bifunctionalization: } 772 \mathrm{~h} \text {; } \\
\text { Apt-AuNPs-SPCE: } \sim 1 \mathrm{~h} 5 \mathrm{~min} \text { ) }\end{array}$ & [50] \\
\hline
\end{tabular}

Au-MS JNPs: Janus Au-mesoporous silica nanoparticles; CEA: carcinoembryonic antigen; Cp: capture probe; CRMs: certified reference materials; DIG: digoxigenin; Dp: detector probe; DPV: differential pulse voltammetry; EIS: electrochemical impedance spectroscopy; Fc-AuNPs-Strep: Ferrocene capped gold nanoparticle-streptavidin conjugates; FITC: fluorescein isothiocyanate; GMO: genetic modified organism; hCp: hairpin capture probe; HER: hydrogen evolution reaction; HBV: Hepatitis B virus; HQ: hydroquinone; HRP: horseradish peroxidase; Mel: melamine; MBs: magnetic beads; MBP: maltose binding protein; MCH: mercaptohexanol; MHA: 6-mercaptohexanoic acid; MSNs: Mesoporous silica nanoparticles; $\mathrm{NH}_{2}$-CC-MNPs: amino functionalized carbon coated magnetic nanoparticles; OEG: oligo(ethylene)glycol; PGE: pencil graphite electrode; SAM: self-assembled monolayer; RR: Roundup Ready; SPCE: screen-printed carbon electrode; SPdCE: screen-printed dual carbon electrodes; Strep: streptavidin; TMB: 3,3' $5,5^{\prime}$-Tetramethylbenzidine; TOA: thioctic acid. 


\section{Main Conclusions, Challenges and Perspectives}

The current generation of functional nanomaterials (AuNPs, magnetic nanomaterials, Janus nanoparticles and AuNWs) allows efficient and rapid static and dynamic biosensing and delivery of nucleic acids at both extracellular and intracellular levels. The unique superparamagnetic anisotropy and self-propulsion properties demonstrated by the selected nanomaterials, mostly metallic, as compared with other carbon and/or polymeric counterparts, are decisive in meeting these particularly challenging applications.

The self-propulsion of metallic NWs (Au-Pt and $\mathrm{Au}$ ) has brought a new paradigm in bioanalysis, proposing, for the first time, the use of the speed/distance of the catalytic Janus Au-Pt ones as analytical signals and the possibility to perform biosensing or delivery in significantly shorter times (just a few minutes compared to hours), allowing the development of near real-time biosensing strategies.

The unique properties and versatility of the use of AuNPs has made it possible to exploit them as electrode materials, catalytic labels, carriers of signal elements or electron transfer regulators in a variety of biosensing methods for the determination of nucleic acids of different natures (mostly DNAs and miRNAs). Their use as electrode materials exploits their unique features to facilitate electronic transfer processes on the electrode surface and provide a large active surface for the immobilization of a large number of thiolated probes with adequate orientation and spacing, thus ensuring maximum efficiency in the hybridization reaction. Also, their great biocompatibility, essential to keep the biological activity of biomolecules attached to their surface, imparts remarkable storage stability to the developed bioplatforms.

In recent years, the superparamagnetic properties of MNPs and, particularly of $\mathrm{Fe}_{3} \mathrm{O}_{4} @ \mathrm{Au}$ MNPs, have been exploited for their use as efficient nanosupports in the development of nucleic acids biosensing strategies with improved sensibility, reduced test time and applicability in complex matrices after minimal test pretreatments. On the other hand, the spatial-selective functionalization of Janus $\mathrm{Au}$-mesoporous silica nanoparticles has been utilized recently to propose attractive nanocarriers of signaling elements in the aptasensing of cancer biomarkers.

Acoustically powered AuNWs have been demonstrated to be active vehicles for efficient cytosolic delivery of active nucleic acids in comparison with the common diffusion-passive methods, thus offering an attractive way to enhance the current landscape of intracellular payloads delivery (at genetic, regulatory and functional levels) for therapeutic purposes and to perform efficient and near real-time biosensing, both extracellularly and intracellularly, without damaging the cells. Although still described to-date as proof-of concept studies, the use of AuNWs as cargo transport vehicles to the cells inside has been demonstrated to overcome physiological barriers for the intracellular delivery of functional molecules (nucleic acids, proteins or sperm cells), thus paving the way for developing highly efficient therapeutic or fertilization applications.

Despite the great advances that have been witnessed in recent years, in order to exploit even further the great potential of these nanoscaled materials and the differential properties they offer with respect to other types of carbon- or polymer-based nanomaterials, additional efforts should be focused on i) maximum simplification of the protocols involved to move from proof-of-concept to more real applications and from laboratory-based to point-of-care test settings, ii) facilitate targeted delivery to specific locations by the incorporation of specific receptors on the nanomaterials surface, and iii) developing methods for multiplexing or co-delivering of multiple payloads. Furthermore, bearing in mind that the manufacturing and/or modification processes of these functional nanomaterials are fairly long (between 16 and $75 \mathrm{~h}$ from information given in Tables 1 and 2), exhaustive studies should be carried out to evaluate their operational stability and variability among different batches prepared in the same way. The improved efficiency and speed for the biosensing or delivering of nucleic acids provided by functional nanomaterials also allows envisioning the development of naked-eye approaches without the need for complex instrumentation.

In recent years, there has been a dizzying progress in the flourishing of new functional nanomaterials, the number of methods available for their preparation and modification, and 
the combination of different nanomaterials to exploit synergistic properties. These great developments, along with the versatility of use they have as surface modifiers, nanosupports and nanolabels/nanocarriers allow the foresight of a high number of innovative designs/combinations of functional nanomaterials and unlimited opportunities, avenues and applications to overcome current and unexpected issues in the highly relevant processes involving biosensing or controlled transport of nucleic acids in real-world applications.

Author Contributions: Writing-review and editing, S.C., M.G., V.S., M.P., P.Y.-S. and J.M.P.; funding acquisition, S.C., P.Y.-S. and J.M.P.

Funding: This research was funded by Spanish Ministerio de Economía y Competitividad, research project CTQ2015-64402-C2-1-R; Ministerio de Ciencia, Innovación y Universidades, research project RTI2018-096135-B-I00; Comunidad de Madrid TRANSNANOAVANSENS-CM Program, Grant S2018/NMT-4349.

Acknowledgments: The financial support of the CTQ2015-64402-C2-1-R (Spanish Ministerio de Economía y Competitividad) and RTI2018-096135-B-I00 (Ministerio de Ciencia, Innovación y Universidades) Research Projects and the TRANSNANOAVANSENS-CM Program from the Comunidad de Madrid (Grant S2018/NMT-4349) are gratefully acknowledged.

Conflicts of Interest: The authors declare no conflict of interest.

\section{References}

1. Paleček, E.; Fojta, M. Magnetic beads as versatile tools for electrochemical DNA and protein biosensing. Talanta 2007, 74, 276-290. [CrossRef]

2. Abi, A.; Mohammadpour, Z.; Zuo, X.; Safavi, A. Nucleic acid-based electrochemical nanobiosensors. Biosens. Bioelectron. 2018, 102, 479-489. [CrossRef]

3. Esteban-Fernández de Avila, B.; Martín, A.; Soto, F.; López-Ramirez, M.A.; Campuzano, S.; Vásquez-Machado, G.M.; Gao, W.; Zhang, L.; Wang, J. Single cell real-time miRNAs sensing based on nanomotors. ACS Nano 2015, 9, 6756-6764. [CrossRef] [PubMed]

4. Esteban-Fernández de Ávila, B.; Angell, C.; Soto, F.; Lopez-Ramirez, M.A.; Báez, D.F.; Xie, S.; Wang, J.; Chen, Y. Acoustically propelled nanomotors for intracellular siRNA delivery. ACS Nano 2016, 10, 4997-5005. [CrossRef] [PubMed]

5. Guo, S.; Wang, E. Synthesis and electrochemical applications of gold nanoparticles. Anal. Chim. Acta 2007, 598, 181-192. [CrossRef] [PubMed]

6. Yeh, Y.-C.; Creran, B.; Rotello, V.M. Gold Nanoparticles: Preparation, Properties, and Applications in Bionanotechnology. Nanoscale 2012, 4, 1871-1880. [CrossRef]

7. Campuzano, S.; Yáñez-Sedeño, P.; Pingarrón, J.M. Nanoparticles for nucleic-acid-based biosensing: Opportunities, challenges, and prospects. Anal. Bioanal. Chem. 2019, 411, 1791-1806. [CrossRef]

8. Cai, H.; Xu, C.; He, P.; Fang, Y. Colloid Au-enhanced DNA immobilization for the electrochemical detection of sequence-specific DNA. J. Electroanal. Chem. 2001, 510, 78-85. [CrossRef]

9. Kang, J.; Li, X.; Wu, G.; Wang, Z.; Lu, X. A new scheme of hybridization based on the Au(nano)-DNA modified glassy carbon electrode. Anal. Biochem. 2007, 364, 165-170. [CrossRef]

10. Zouari, M.; Campuzano, S.; Pingarrón, J.M.; Raouafi, N. Ultrasensitive determination of microribonucleic acids in cancer cells with nanostructured-disposable electrodes using the viral protein $\mathrm{p} 19$ for recognition of ribonucleic acid/microribonucleic acid homoduplexes. Electrochim. Acta 2018, 262, 39-47. [CrossRef]

11. Zouari, M.; Campuzano, S.; Pingarrón, J.M.; Raouafi, N. Amperometric Biosensing of miRNA-21 in serum and cancer cells at nanostructured platforms using anti-DNA-RNA hybrid antibodies. ACS Omega 2018, 3, 8923-8931. [CrossRef] [PubMed]

12. de la Escosura-Muñiz, A.; Baptista-Pires, L.; Serrano, L.; Altet, L.; Francino, O.; Sánchez, A.; Merkoçi, A. Magnetic bead/gold nanoparticle double-labeled primers for electrochemical detection of isothermal amplified Leishmania DNA. Small 2016, 12, 205-213. [CrossRef] [PubMed]

13. Wan, Y.; Wang, P.; Su, Y.; Wang, L.; Pan, D.; Aldalbahi, A.; Yang, S.; Zuo, X. Nanoprobe-initiated enzymatic polymerization for highly sensitive electrochemical DNA detection. ACS Appl. Mater. Interfaces 2015, 7, 25618-25623. [CrossRef] [PubMed] 
14. Wang, Z.; Zhang, J.; Zhu, C.; Wu, S.; Mandler, D.; Marks, R.S.; Zhang, H. Amplified detection of femtomolar DNA based on a one-to-few recognition reaction between DNA-Au conjugate and target DNA. Nanoscale 2014, 6, 3110-3115. [CrossRef]

15. Wang, Q.; Gao, F.; Ni, J.; Liao, X.; Zhang, X.; Lin, Z. Facile construction of a highly sensitive DNA biosensor by in-situ assembly of electro-active tags on hairpin-structured probe fragment. Sci. Rep. 2016, 6, 22441. [CrossRef]

16. Zouari, M.; Campuzano, S.; Pingarrón, J.M.; Raouafi, N. Femtomolar direct voltammetric determination of miRNAs in sera of cancer patients using enzymeless sandwich hybridization biosensors. Anal. Chim. Acta. submitted.

17. Yang, Y.; Li, C.; Yin, L.; Liu, M.; Wang, Z.; Shu, Y.; Li, G. Enhanced charge transfer by gold nanoparticle at DNA modified electrode and its application to label-free DNA Detection. ACS Appl. Mater. Interfaces 2014, 6, 7579-7584. [CrossRef]

18. Freitas, M.; Couto, M.S.; Barroso, M.F.; Pereira, C.; de-los-Santos-Álvarez, N.; Miranda-Ordieres, A.J.; Lobo-Castañón, M.J.; Delerue-Matos, C. Highly monodisperse $\mathrm{Fe}_{3} \mathrm{O}_{4} @ \mathrm{Au}$ superparamagnetic nanoparticles as reproducible platform for genosensing genetically modified organisms. ACS Sens. 2016, 1, 1044-1053. [CrossRef]

19. Rocha-Santos, T.A.P. Sensors and biosensors based on magnetic nanoparticles. Trac. Trends Anal. Chem. 2014, 62, 28-36. [CrossRef]

20. Yáñez-Sedeño, P.; Campuzano, S.; Pingarrón, J.M. Magnetic particles coupled to disposable screen-printed transducers for electrochemical biosensing. Sensors 2016, 16, 1585. [CrossRef]

21. Reverté, L.; Prieto-Simón, B.; Campàs, M. New advances in electrochemical biosensors for the detection of toxins: Nanomaterials, magnetic beads and microfluidics systems. A review. Anal. Chim. Acta 2016, 908, 8-21.

22. Serafín, V.; Torrente-Rodríguez, R.M.; Batlle, M.; García de Frutos, P.; Campuzano, S.; Yáñez-Sedeño, P.; Pingarrón, J.M. Comparative evaluation of the performance of electrochemical immunosensors using magnetic microparticles and nanoparticles. Application to the determination of tyrosine kinase receptor AXL. Microchim. Acta 2017, 184, 4251-4258.

23. Kudr, J.; Haddad, Y.; Richtera, L.; Heger, Z.; Cernak, M.; Adam, V.; Zitka, O. Magnetic nanoparticles: From design and synthesis to real world applications. Nanomaterials 2017, 7, 243. [CrossRef] [PubMed]

24. Kudr, J.; Klejdus, B.; Adam, V.; Zitka, O. Magnetic solids in electrochemical analysis. Trac Trends Anal. Chem. 2018, 98, 104-113. [CrossRef]

25. Pastucha, M.; Farka, Z.; Lacina, K.; Mikušová, Z.; Skládal, P. Magnetic nanoparticles for smart electrochemical immunoassays: A review on recent developments. Microchim. Acta 2019, 186, 312. [CrossRef]

26. Loaiza, O.A.; Jubete, E.; Ochoteco, E.; Cabanero, G.; Grande, H.; Rodriguez, J. Gold coated ferric oxide nanoparticles based disposable magnetic genosensors for the detection of DNA hybridization processes. Biosens. Bioelectron. 2011, 26, 2194-2200. [CrossRef] [PubMed]

27. Li, K.; Lai, Y.J.; Zhang, W.; Jin, L.T. $\mathrm{Fe}_{2} \mathrm{O}_{3} @$ Au core/shell nanoparticle-based electrochemical DNA biosensor for Escherichia coli detection. Talanta 2011, 84, 607-613. [CrossRef]

28. Zhao, J.; Lin, F.; Yi, Y.; Huang, Y.; Li, H.; Zhang, Y.; Yao, S. Dual amplification strategy of highly sensitive thrombin amperometric aptasensor based on chitosan-Au nanocomposites. Analyst 2012, 137, 3488-3495. [CrossRef]

29. Plácido, A.; Pereira, C.; Guedes, A.; Barroso, M.F.; Miranda-Castro, R.; de-los-Santos-Álvarez, N.; Delerue-Matos, C. Electrochemical genoassays on gold-coated magnetic nanoparticles to quantify genetically modified organisms (GMOs) in food and feed as GMO percentage. Biosens. Bioelectron. 2018, 110, 147-154. [CrossRef]

30. Plácido, A.; Pereira, C.; Barroso, M.F.; de-los-Santos-Álvarez, N.; Delerue-Matos, C. Chronoamperometric magnetogenosensing for simultaneous detection of two Roundup Ready ${ }^{\mathrm{TM}}$ soybean lines: GTS 40-3-2 and MON89788. Sens. Actuators B Chem. 2019, 283, 262-268.

31. Pal, S.; Alocilja, E.C. Electrically active magnetic nanoparticles as novel concentrator and electrochemical redox transducer in Bacillus anthracis DNA detection. Biosens. Bioelectron. 2010, 26, 1624-1630. [CrossRef] [PubMed] 
32. Situ, B.; Cao, N.; Li, B.; Liu, Q.; Lin, L.; Dai, Z.; Zou, X.; Cai, Z.; Wang, Q.; Yan, X.; et al. Sensitive electrochemical analysis of BRAFV600E mutation based on an amplification-refractory mutation system coupled with multienzyme functionalized $\mathrm{Fe}_{3} \mathrm{O}_{4} / \mathrm{Au}$ nanoparticles. Biosens. Bioelectron. 2013, 43, 257-263. [CrossRef] [PubMed]

33. Reddy, L.H.; Arias, J.L.; Nicolas, J.; Couvreur, P. Magnetic nanoparticles: Design and characterization, toxicity and biocompatibility, pharmaceutical and biomedical applications. Chem. Rev. 2012, 112, 5818-5878. [CrossRef] [PubMed]

34. Urbanova, V.; Magro, M.; Gedanken, A.; Baratella, D.; Vianello, F.; Zboril, R. Nanocrystalline iron oxides, composites, and related materials as a platform for electrochemical, magnetic, and chemical biosensors. Chem. Mater. 2014, 26, 6653-6673. [CrossRef]

35. Güzel, R.; Üstündağ, Z.; Ekşi, H.; Keskin, S.; Taner, B.; Durgun, Z.G.; Turan, A.A.İ.; Solak, A.O. Effect of Au and Au@Ag core-shell nanoparticles on the SERS of bridging organic molecules. J. Colloid Interface Sci. 2010, 351, 35-42.

36. Yola, M.L.; Eren, T.; Atar, N. A novel and sensitive electrochemical DNA biosensor based on Fe@Au nanoparticles decorated grapheme oxide. Electrochim. Acta 2014, 125, 38-47. [CrossRef]

37. Xu, Y.; Wang, E. Electrochemical biosensors based on magnetic micro/nano particles. Electrochim. Acta 2012, 84, 62-73. [CrossRef]

38. Pan, J.; Yang, Q. Antibody-functionalized magnetic nanoparticles for the detection of carcinoembryonic antigen using a flow-injection electrochemical device. Anal. Bioanal. Chem. 2007, 388, 279-286. [CrossRef]

39. Tran, L.D.; Nguyen, B.H.; Hieu, N.V.; Tran, H.V.; Nguyen, H.L.; Nguyen, P.X. Electrochemical detection of short HIV sequences on chitosan $/ \mathrm{Fe}_{3} \mathrm{O}_{4}$ nanoparticle based screen-printed electrodes. Mater. Sci. Eng. C 2011, 31, 477-485. [CrossRef]

40. Yi, Y.; Sanchez, L.; Gao, Y.; Yu, Y. Janus particles for biological imaging and sensing. Analyst 2016, 141, 3526-3539. [CrossRef]

41. Shao, Z.; Cao, H.; Yang, Y.; Chen, X. Intelligent Janus nanoparticles for intracellular real-time monitoring of dual drug release. Nanoscale 2016, 8, 6754-6760.

42. Schrittwieser, S.; Pelaz, B.; Parak, W.J.; Lentijo-Mozo, S.; Soulantica, K.; Dieckho, J.; Ludwig, F.; Guenther, A.; Tschöpe, A.; Schotter, J. Homogeneous biosensing based on magnetic particle labels. Sensors 2016, 16, 828. [CrossRef] [PubMed]

43. Yánez-Sedeño, P.; Campuzano, S.; Pingarrón, J.M. Janus particles for (bio)sensing. Appl. Mat. Today 2017, 9, 276-288. [CrossRef]

44. Campuzano, S.; Gamella, M.; Serafín, V.; Pedrero, M.; Yáñez-Sedeño, P.; Pingarrón, J.M. Magnetic Janus particles for static and dynamic (bio)sensing. Magnetochemistry 2019, 5, 47. [CrossRef]

45. Jung, C.W.; Jalani, G.; Ko, J.; Choo, J.; Lim, D.W. Synthesis, characterization, and directional binding of anisotropic biohybrid microparticles for multiplexed biosensing. Macromol. Rapid Commun. 2014, 35, 56-65. [CrossRef]

46. Li, B.; Wang, M.; Chen, K.; Cheng, Z.; Chen, G.; Zhang, Z. Synthesis of biofunctional Janus particles. Macromol. Rapid Commun. 2015, 36, 1200-1204. [CrossRef]

47. Sánchez, A.; Díez, P.; Martínez-Ruíz, P.; Villalonga, R.; Pingarrón, J.M. JanusAu-mesoporous silica nanoparticles as electrochemical biorecognition-signaling system. Electrochem. Commun. 2013, 30, 51-54. [CrossRef]

48. Boujakhrout, A.; Sánchez, E.; Díez, P.; Sánchez, A.; Martínez-Ruiz, P.; Parrado, C.; Pingarrón, J.M.; Villalonga, R. Single-walled carbon nanotubes/Au-mesoporoussilica Janus nanoparticles as building blocks for the preparation of a bienzyme biosensor. ChemElectroChem 2015, 2, 1735-1741. [CrossRef]

49. Paniagua, G.; Villalonga, A.; Eguílaz, M.; Vegas, B.; Parrado, C.; Rivas, G.; Díez, P.; Villalonga, R. Amperometric aptasensor for carcinoembryonic antigen based on the use of bifunctionalized Janus nanoparticles as biorecognition-signaling element. Anal. Chim. Acta 2019, 1061, 84-91. [CrossRef]

50. Jimenez-Falcao, S.; Parra-Nieto, J.; Pérez-Cuadrado, H.; Martínez-Máñez, R.; Martínez-Ruiz, P.; Villalonga, R. Avidin-gated mesoporous silica nanoparticles for signal amplification in electrochemical biosensor. Electrochem. Commun. 2019, 108, 109556. [CrossRef]

51. Campuzano, S.; Kagan, D.; Orozco, J.; Wang, J. Motion-driven sensing and biosensing using electrochemically propelled nanomotors. Analyst 2011, 136, 4621-4630. [CrossRef] [PubMed] 
52. Kagan, D.; Calvo-Marzal, P.; Balasubramanian, S.; Sattayasamitsathit, S.; Manesh, K.M.; Flechsig, G.-U.; Wang, J. Chemical sensing based on catalytic nanomotors: Motion-based detection of trace silver. J. Am. Chem. Soc. 2009, 131, 12082-12083. [CrossRef] [PubMed]

53. Kline, T.R.; Paxton, W.F.; Mallouk, T.E.; Sen, A. Catalytic nanomotors: Remote-controlled autonomous movement of striped metallic nanorods. Angew. Chem. Int. Ed. 2005, 44, 744-746. [CrossRef] [PubMed]

54. Jurado-Sánchez, B. Nanoscale biosensors based on self-propelled objects. Biosensors 2018, 8, 59. [CrossRef]

55. Wang, W.; Li, S.; Mair, L.; Ahmed, S.; Huang, T.J.; Mallouk, T.E. Acoustic propulsion of nanorod motors inside living cells. Angew. Chem. Int. Ed. 2014, 53, 3201-3204. [CrossRef]

56. Wu, J.; Balasubramanian, S.; Kagan, D.; Manesh, K.M.; Campuzano, S.; Wang, J. Motion-based DNA detection using catalytic nanomotors. Nat. Commun. 2010, 1, 36. [CrossRef]

57. Wang, J. Self-propelled affinity biosensors: Moving the receptor around the sample. Biosens. Bioelectron. 2016, 76, 234-242. [CrossRef]

58. Qualliotine, J.R.; Bolat, G.; Beltrán-Gastélum, M.; Esteban-Fernández de Ávila, B.; Wang, J.; Califano, J.A. Acoustic nanomotors for detection of human papilloma virus-associated head and neck cancer. Otolaryngol. Head Neck Surg. 2019, 161, 814-822. [CrossRef]

59. Hansen-Bruhn, M.; Esteban-Fernández de Ávila, B.; Beltrán-Gastélum, M.; Zhao, J.; Ramírez-Herrera, D.E.; Angsantikul, P.; Vesterager Gothelf, K.; Zhang, L.; Wang, J. Active intracellular delivery of a Cas9/sgRNA complex using ultrasound-propelled nanomotors. Angew. Chem. Int. Ed. 2018, 57, 2657-2661. [CrossRef]

60. Altay, C.; Senay, R.H.; Eksina, E.; Congur, G.; Erdem, A.; Akgol, S. Development of amino functionalized carbon coated magnetic nanoparticles and their application to electrochemical detection of hybridization of nucleic acids. Talanta 2017, 164, 175-182. [CrossRef]

61. Sousa, J.B.; Ramos-Jesus, J.; Silva, L.C.; Pereira, C.; de-los-Santos-Alvarez, N.; Fonseca, R.A.S.; Miranda-Castro, R.; Delerue-Matos, C.; Ribeiro Santos Junior, J.; Barroso, M.F. Fe ${ }_{3} \mathrm{O}_{4} @ A$ u nanoparticles-based magnetoplatform for the HMGA maize endogenous gene electrochemical genosensing. Talanta 2020, 206, 120220. [CrossRef] [PubMed]

(C) 2019 by the authors. Licensee MDPI, Basel, Switzerland. This article is an open access article distributed under the terms and conditions of the Creative Commons Attribution (CC BY) license (http://creativecommons.org/licenses/by/4.0/). 